\title{
KILKA SŁÓW O PEWNYM SŁODKIM SOSIE, CZYLI O DIETETYCE I MATERIA MEDICA W DE OBSERVATIONE CIBORUM ANTIMUSA ${ }^{1}$
}

Maciej Kokoszko

Uniwersytet Łódzki http://orcid.org/0000-0002-9563-2902

\section{ABSTRACT \\ A FEW WORDS ON A CERTAIN SWEET SAUCE, OR ON DIETETICS AND MATERIA MEDICA IN DE OBSERVATIONE CIBORUM BY ANTHIMUS}

The article analyses reading of the fragment ...in dulci piper habente, parum cariofili et gingiber, costum et spicam nardi vel folium included in chapter 13 of De observatione ciborum by a Byzantine doctor Anthimus. The author attempts to reconstruct (on the basis of topical culinary, agronomic and encyclopaedic literature) the technology employed in preparing of the said sauce, and claims (having analysed culinary and medical sources) that the term folium used in the recipe denotes tejpat (Cinnamomum tamala [Buch.-Ham.] T. Nees \& Eberm). The research leads to the conclusion that Anthimus' literary advice is based on his in-depth medical knowledge, which not only included a theory borrowed from a number of authorities but also resulted from his personal therapeutic experience.

Keywords: history of ancient and Byzantine culinary art, history of ancient and Byzantine medicine, Anthimus, De observatione ciborum.

Słowa kluczowe: historia kuchni antycznej i bizantyńskiej, historia medycyny antycznej i bizantyńskiej, Antimus, De observatione ciborum.

\section{KILKA UWAG O DZIELE ANTIMUSA}

Dzieło Antimusa, znane jako De observatione ciborum, jest zbiorem porad dietetycznych, skierowanych do Teuderyka, władcy Franków (511-534 r. n.e.). Zostało

${ }^{1}$ Artykuł został napisany dzięki stypendium Fundacji De Brzezie Lanckorońskich przyznanemu w $2017 \mathrm{r}$.

Adres do korespondencji: mkokoszko@komandor.pl; maciej.kokoszko@uni.lodz.pl 
ono napisane po łacinie, najprawdopodobniej w pierwszej połowie VI wieku². Jego autor identyfikowany jest z lekarzem, którego wspomniał Malchus z Filadelfii (VI w. n.e.), a który za udział w spisku przeciw cesarzowi Zenonowi (474-491 r. n.e.) został wygnany z Konstantynopola ${ }^{3}$. Miało to miejsce w roku 478. Dalsze koleje losu medyka są niepewne, aczkolwiek wielu uważa, że Antimus przebywał wśród Gotów. Następnie został wysłany przez Teodoryka Wielkiego (471-526 r. n.e.) w poselstwie na dwór Franków, a traktat De observatione ciborum był darem dla Teuderyka inspirowanym przez władcę Gotów ${ }^{4}$. Hipotezy te nie mają jednak silnej podbudowy faktograficznej, co udowodnił Yitzhak Hen. Zaproponował on alternatywną wersję losów Antimusa. Wedle Hena pomiędzy latami 491 a 497 autor De observatione ciborum miał powrócić do Konstantynopola, a następnie, przynajmniej dwukrotnie, posłować do Franków z ramienia cesarza Anastazjusza (491-518 r. n.e.). Natomiast dzieło życia Antimusa nie powstało z inicjatywy Teodoryka Wielkiego, ale na zamówienie samego władcy Franków ${ }^{5}$.

De observatione ciborum Antimusa jest dziełkiem ciekawym dla badaczy, gdyż możliwym do interpretacji pod różnymi kątami. Dla historyka medycyny jest ono świadectwem ewolucji myśli dietetycznej, ale też rozwoju materia medica do początku VI wieku n.e. ${ }^{6}$ Historyk sztuki kulinarnej może mieć tendencję do analizy tego traktatu pod kątem informacji na temat kuchni śródziemnomorskiej ${ }^{7}$, podczas

${ }^{2}$ Około 516 lub 523 r. n.e. - M. Grant, Introduction [w:] Anthimus, On the Observance of Foods. De observatione ciborum, ed., transl. M. Grant, Blackawton-Totnes 2007, s. 23-24. Mark Grant uważa, że pierwsza opcja jest bardziej prawdopodobna.

${ }^{3}$ Malchus, 15, 422, 30-39.

${ }^{4}$ Wykaz najważniejszej literatury por. C. Deroux, Anthime, un médecin gourmet du début des temps mérovingiens, „Revue Belge de Philologie et d'Histoire” 2002, vol. 80, no. 4, s. 1107-1108.

${ }_{5}^{5}$ Y. Hen, Food and Drink in Merovingian Gaul [w:] Tätigkeitsfelder und Erfahrungshorizonte des ländlichen Menschen in der frühmittelalterlichen Grundherrschaft (bis ca. 1000): Festschrift für Dieter Hägermann zum 65. Geburtstag, ed. B. Kasten, München 2006, s. 100-103.

${ }^{6}$ Historycy medycyny zwykle doceniają zainteresowanie Antimusa dietetyką jako ważną gałęzią medycyny - C. Deroux, Des traces inconnues de la "Diététique" d'Anthime dans un manuscrit du Vatican “(Reg. Lat. 1004)”, „Latomus” 1974, vol. 33, no. 3, s. 680-687; idem, Anthime, passim; P.Prioreschi, A History of Medicine, vol. V. Medieval Medicine, Omaha, NE2003, s. 146-147; V. Nutton, Ancient Medicine, London-New York 2004, s. 301; J. Scarborough, Anthimus (of Constantinople?) (ca 475-525 CE) [w:] The Encyclopedia of Ancient Natural Scientists. The Greek Tradition and its Many Heirs, eds. P.T. Keyser, G. Irby-Massie, London-New York 2008, s. 91-92. Klaus-Dietrich Fis cher (Ein brennendes Problem: Anthimus, praef., p. 3, 6, Liechtenhan, „Latomus” [Bruxelles] 1989, vol. 48, no. 4, s. 880-881) sugerował, że dziełko Antimusa zawiera także informacje dotyczące weterynarii, a dokładnie kauteryzacji koni cierpiących na dyzenterię. Por. C. Deroux, The Allusion by Anthimus the Physician to the Cauterisation of Horses (De obs. cib., praef., p. 3, l. 6-8 Liechtenhan) [w:] Studies in Latin Literature and Roman History, ed. C. Deroux, Bruxelles 2005, s. 484-493. Carl Deroux zajął się także śladami toksykologii (Anthime et les tourterelles: un cas d'intoxication alimentaire au très haut moyen âge [w:] Maladie et maladies dans les textes latins antiques et médiévaux. Actes du ve Colloque international «Textes médicaux latins» [Bruxelles, 4-6 septembre 1995], ed. C. Deroux, Bruxelles 1998, s. 366-381) i diagnostyki (Le médecin Anthimus et le vocabulaire de la diagnose [De obs. cib. 25: agnoscens], „Latomus” [Bruxelles] 2015, vol. 74, no. 2, s. 491-493) w twórczości Antimusa.

${ }^{7}$ Antimus jest zwykle prezentowany jako autor, który zachował wiele istotnych informacji na temat kuchni Bizancjum. Por. m.in.: C. Deroux, Anthime, passim; A. Dalby, Tastes of Byzantium. The Cuisine of a Legendary Empire, London-New York 2010, s. 173-177, 188-189, 209-210 etc.; J. Koder, Cuisine 
gdy filolog będzie patrzył na epistula ad Teudericum regem Francorum jako na materiał pokazujący bogactwo leksykalne i ewolucję języka łacińskiego ${ }^{8}$. Dodajmy, iż starożytnicy zaliczać będą to opusculum do źródeł powstałych w okresie kończącego się antyku, z kolei bizantyniści klasyfikować je będą jako wyraz myśli okresu wczesnobizantyńskiego.

Niniejszy artykuł analizuje dane przekazane przez Antimusa z punktu widzenia badacza historii myśli medycznej, traktującego De observatione ciborum jako zbiór rad dotyczących zasad odżywiania, a zatem jako regimen ${ }^{9}$ oparty na regułach dietetyki. Ta gałąź medycyny w momencie komponowania interesującego nas traktatu miała już niemal 1000 lat tradycji, a zatem nic dziwnego, że przenika go do głębi. Założenia dietetyki greckiej obecne są choćby w zdaniu z proemium, w którym lekarz $^{10}$ expressis verbis przypisuje stan zdrowia odpowiedniej diecie (...prima sanitas hominum in cibis congruis constat ${ }^{11}$ ), oraz we fragmencie, który opisuje skutki spożywania niewłaściwego pożywienia i tłumaczy je jako wynik zakłócenia procesu trawienia oraz przyswajania pokarmu ${ }^{12}$. Uzupełnia te wypowiedzi uwaga brzmiąca:

and Dining in Byzantium [w:] Byzantine Culture. Papers from the Conference 'Byzantine Days of Istanbul' Held on the Occasion of Istanbul being European Cultural Capital 2010 Istanbul, May 21-23 2010, ed. D. S ake l, Ankara 2014, s. 423, 428, 431-434; idem, Die Byzantiner. Kultur und Alltag in Mittelalter, Wien-Köln-Weimar 2016, s. 207, 213, 216 etc. Ukazywany jest także jako autor prezentujący kuchnię Galii, por.: B. Effros, Creating Community with Food and Drinks in Merovingian Gaul, New YorkHoundmills, Basingstoke 2003, s. 7, 61-68; C. Deroux, The Franks and Bacon According to Doctor Anthimus (De obs. cib. 14) [w:] Studies in Latin Literature and Roman History, ed. C. Deroux, Bruxelles 2008, s. 518-528.

${ }^{8}$ Dziełko Antimusa jest najczęściej badane pod kątem jego leksyki, która powoduje rozliczne trudności interpretacyjne. Por. m.in.: G.M. Messing, Remarks on Anthimus De observatione ciborum, „Classical Philology” 1942, vol. 37, no. 2, s. 150-158; M. Grant, A Problematical Word in Anthimus ' "De Observatione Ciborum Epistula” 43, „Rheinisches Museum für Philologie, Neue Folge” 1993, vol. 136, no. 3/4, s. 377-379 etc. Niekiedy badacze klasyfikują leksykę wedle jej pochodzenia etnicznego. Por. M. Caparrini, Per un approfondimento dei germanismi dell'Epistula Anthimi de observatione ciborum: bridum/spiss, sodinga/prue, „Linguistica e Filologia” 2009, vol. 29, s. 179-196. Ciekawy jest również w De observatione ciborum aspekt dwujęzyczności autora tego traktatu. Por. J. Adams, Bilingualism and the Latin Language, Cambridge 2003, s. 496-497.

9 Podzielam zatem pogląd Liliane Plouvier (L'alimentation carnée au Haut Moyen Âge d'après le De observatione ciborum d'Anthime et les Excerpta de Vinidarius, „Revue belge de philologie et d'histoire" 2002, vol. 80, no. 4, s. 1358-1360).

${ }^{10}$ De observatione ciborum interpretowane jest przeze mnie jako świadectwo praktyki medycznej wykonywanej przez Antimusa. Tę ostatnią konkluzję potwierdzają jego słowa istud et ego in tempore meo probavi in rovincia mea (Antimus, 25, p. 14, 4), które opisują jego interwencję mającą na celu wyleczenie ofiar zatrucia mięsem turkawek - C. Deroux, Anthime et les tourterelles, s. 366-381. To samo rozumiemienie słów Antimusa obecne jest w niemieckim thumaczeniu tego fragmentu autorstwa Edwarda Liechtenhana (E. Liechtenhan, Brief des Anthimus des erlauchten Comes und Gesandten and den ruhmreichen Theoderich, der König der Franken, über Speisediät [w:] Anthimi De observatione ciborum ad Theodoricum regem Francorum epistula, iteratis curis edidit et in linguam Germanicam transtulit E. Liechtenhan, Berlin 1963, s. 39) oraz we francuskiej jego wersji pióra Deroux (Anthime et les tourterelles, s. 370). Ten drugi (Anthime, s. 1112) zwraca jednak uwagę na niejednoznaczność słów Antimusa.

${ }^{11}$ Antimus, Proemium, p. 1, 8-9.

${ }^{12}$ Ibidem, p. 1, 9-2, 2. 
...si autem bene praeparati fuerint cibi, digestio bona et dulcis fiet, et humores boni nutriuntur... ${ }^{13}$, która uzasadnia zainteresowanie autora sposobami przygotowywania pokarmów, a zatem sztuką kulinarną. Dietetyka łączyła się z materia medica, czyli wiedzą o substancjach leczniczych, z których znaczna część była pokarmami ${ }^{14}$. Przekonanie o terapeutycznej roli substancji, które spożywamy, widoczne jest niemal na każdej stronie traktatu, na przykład tej, na której lekarz we fragmencie odnoszącym się do suszonych fig ${ }^{15}$ wprost przypisuje im działanie lecznicze w konkretnych terapiach, jak w kuracji początkowych stadiów kataru, podrażnień gardła oraz chrypy.

Teoria Antimusa nie różni się od tej, którą stworzyli jego poprzednicy i uprawiali jego współcześni. Jej podstawą są (obecne już w Corpus Hippocraticum ${ }^{16}$, ale skanonizowane dopiero przez Galena) nauki na temat czterech jakości (zimno, ciepło, wilgoć, suchość), czterech elementów podstawowych (ziemia, woda, powietrze, ogień) oraz czterech soków organicznych (flegma, krew, żółć, czarna żółć), których właściwa proporcja decyduje o harmonii wewnętrznej organizmu człowieka, a zatem o jego zdrowiu. Cechy pokarmu przyczyniają się do jego utrzymania, zakłócenia bądź przywrócenia, przy czym ostateczny wynik tego procesu zależny jest także od warunków zewnętrznych, które wpływają na organizm ${ }^{17}$.

Traktat Antimusa w sposób jednoznaczny odnosi się do wymienionych czterech jakości, a co za tym idzie - do analogicznych działań pokarmów, co widać choćby na podstawie fragmentu, w którym autor, charakteryzując jęczmień, określa jego naturę jako mokrą (czy też „nawilżjącą”) i chłodną (lub raczej „ochładzającą”) ${ }^{18}$. Łączy też cechy pokarmów z jakościami przypisywanymi humorom, wskazując, iż cechy tych pierwszych warunkują charakterystykę tych drugich. Dlatego pisze na przykład, że ostrygi są z natury swej ochładzające, powodując powstanie flegmy, a więc humoru zimnego i mokrego ${ }^{19}$. Antimus bez wątpienia przyswoił sobie naukę o temperamen-

${ }_{13}$ Ibidem, p. 2, 3-4.

${ }^{14}$ Zgodnie z zasadami antycznej, a później bizantyńskiej sztuki medycznej, z której czerpał Antimus, poszczególne pokarmy odznaczały się konkretnymi działaniami, które można było wykorzystać w sztuce tworzenia lekarstw, a zatem w farmakologii. Na ten temat, por. np.: M. Kokoszko, K. Jagusiak, Z. Rzeźnicka, Dietetyka i sztuka kulinarna antyku i wczesnego Bizancjum (II-VII w.), część I, Zboża $i$ produkty zbożowe w źródlach medycznych antyku $i$ wczesnego Bizancjum (II-VII w.), Łódź 2014, s. 5-26; L. Totelin, When Foods Become Remedies in Ancient Greece: The Curious Case of Garlic and Other Substances, „Journal of Ethnopharmacology” 2015, vol. 167, s. 30-37; J. Wilkins, Good Food and Bad: Nutritional and Pleasurable Eating in Ancient Greece, ,Journal of Ethnopharmacology” 2015, vol. 167, s. 7-10; Z. Rzeźnicka, M. Kokoszko, Dietetyka i sztuka kulinarna antyku i wczesnego Bizancjum (II-VII w.), część III, Ab ovo ad yó $\alpha$. Jajka, mleko i produkty mleczne w medycynie $i$ w sztuce kulinarnej (I-VII w.), Łódź 2016, s. 17-49, 70-81, 89-94, 106-120, 139-143, 171-181; L.M.V. Totelin, Therapeutics [w:] The Cambridge Companion to Hippocrates, ed. P.E. Pormann, Cambridge-New York 2018, s. 203-216; Z. Rzeźnicka, M. Kokoszko, Milk and Dairy Products in the Medicine and Culinary Art of Antiquity and Early Byzantium (1st-7th Centuries AD), Łódź-Kraków 2020, s. 26-37, 64-75, 100-103, 131-137.

${ }^{15}$ Antimus, 93, 33, 1-3. Inne przykłady por. C. Deroux, Anthime, s. 1111-1112.

16 V. Nutton, Ancient Medicine, London-New York 2005, s. 53-71.

${ }^{17}$ Ibidem, s. 72-86.

${ }^{18}$ Hordei natura humida et frigida... - Antimus, 2, p. 4, 13.

19 Ostria ... frigida sunt et fleumatica... - Antimus, 49, p. 20, 7-8. 


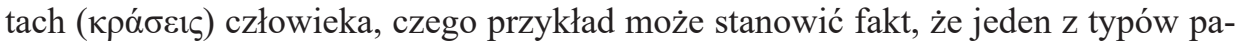
cjentów, których miał na myśli, pisząc swe rozważania, nazywa flegmatykami ${ }^{20}$.

De observatione ciborum to jednak nie tylko zbiór praktycznych rad dotyczących przyrządzania pokarmów, wykorzystujący (zgodnie z prawidłami dietetyki) wiedzę $\mathrm{z}$ dziedziny materia medica na temat przypisywanych im właściwości. To również wyraz tej samej dążności do podsumowania dorobku poprzedzających go pokoleń lekarzy $^{21}$, jaką odnajdujemy w encyklopediach medycznych Orybazjusza (IV w. n.e.) ${ }^{22}$, Aecjusza z Amidy (VI w. n.e. $)^{23}$ i Pawła z Eginy (VII w. n.e.) ${ }^{24}$. Choć na pierwszy rzut oka uproszczony, wykład Antimusa opiera się na przyswojeniu nauki autorytetów medycyny, o czym świadczą chociażby dwa fragmenty zawarte we wstępie do jego traktatu. W pierwszym lekarz zapewnia adresata swego dzieła, iż jego warstwa merytoryczna jest zasobem wiedzy opartym na praecepta auctorum medicinalium... ${ }^{25}$ Drugi mówi, że treść epistula została skomponowana ...secundum praecepta diversorum auctorum... ${ }^{26}$ Rzeczywiście - odniesienia do solidnej bazy teoretycznej zostały wprowadzone do licznych rozdziałów zawierających treści szczegółowe, w tym do fragmentów 23, 25, 26, 36 i 57.

Powyższe konstatacje skutkują metodą przyjętą w niniejszej analizie, która polega na skonstruowaniu komentarza do 13 rozdziału De observatione ciborum w oparciu nie tylko o literaturę kulinarną, ale przede wszystkim dorobek dietetyki i materia

${ }^{20}$ Phlegmatici-Antimus, 60, p. 23, 5 .

${ }^{21}$ Kwestia ciągłości tradycji medycznej w czasach antyku i wczesnego Bizancjum w ostatnich latach jest stosunkowo często podnoszona w światowej nauce, por. np.: Ph. van der Eijk, Principles and Practices of Compilation and Abbreviation in the Medical "Encyclopaedias" of Late Antiquity [w:] Condensing Texts - Condensed Texts, eds. M. Horster, Ch. Reitz, Stuttgart 2010, s. 519-554; E. Gowling, Aëtius' Extraction of Galenic Essence: A Comparison Between Book 1 of Aetius' Libri Medicinales and Galen's On Simple Medicines [w:] Collecting Recipes. Byzantine and Jewish Pharmacology in Dialogue, eds. L. Lehmhaus, M. Martelli, Boston-Berlin 2017, s. 83-101; A. Touwaide, Medicine and Pharmacy [w:] A Companion to Byzantine Science, ed. S. Lazaris, Leiden-Boston 2020, s. 364-367.

${ }^{22} \mathrm{Na}$ temat Orybazjusza por.: B. Baldwin, The Career of Oribasius, „Acta Classica” 1975, vol. 18, s. 85-97; M. Grant, Oribasios and Medical Dietetics or the Three Ps [w:] Food in Antiquity, eds. J. Wilkins, D. Harvey, M. Dobson, Exeter 1995, s. 368-379; R. de Lucia, Oreibasios v. Pergamon [w:] Antike Medizin. Ein Lexikon, ed. K.-H. Leven, München 2005, kol. 660-661; K. Jagusiak, M. Kokoszko, Życie i kariera Orybazjusza w świetle relacji źródłowych, „Przegląd Nauk Historycznych” 2011, t. 10, nr 1, s. 5-21; iidem, Pisma Orybazjusza jako źródło informacji o pożywieniu ludzi w późnym Cesarstwie Rzymskim, „Vox Patrum” 2013, vol. 59, s. 339-357.

${ }^{23}$ O praktyce i nauce Aecjusza z Amidy, por.: H. Hunger, Die hochsprachliche profane Literatur der Byzantiner, vol. I, München 1978, s. 294-296; V. Nutton, From Galen to Alexander. Aspects of Medicine and Medical Practice in Late Antiquity, „Dumbarton Oaks Papers” 1984, vol. 38, s. 1-14; J. Scarborough, Early Byzantine Pharmacology, „Dumbarton Oaks Papers” 1984, vol. 38, s. 224-226; A. Garzya, Aetios v. Amida [w:] Antike Medizin, kol. 19-20; V. Nutton, Ancient Medicine, s. 295.

${ }^{24}$ Na temat Pawła z Eginy, por.: H. Diller, Paulos (23) [w:] RE, vol. 18.4, Stuttgart 1949, kol. 2386 2397; P. Pormann, The Oriental Tradition of Paul of Aegina's Pragmateia, Leiden 2004, passim; idem, Paulos v. Aigina [w:] Antike Medizin, kol. 681-682; P. Bouras-Vallianatos, Galen in Late Antique Medical Handbooks [w:] Brill's Companion to the Reception of Galen, eds. P. Bouras-Vallianatos, B. Zipser, Leiden-Boston 2019, s. 43.

${ }^{25}$ Antimus, Proemium, p. 1, 6-7.

${ }^{26}$ Ibidem, p. 4, 4-5. 
medica. Z powodu obszerności materiału analiza ta nie może jednak obejmować wszystkich zagadnień poruszonych przez Antimusa w rzeczonym rozdziale, ale skupia się wyłącznie na recepturze sosu polecanego przez autora do zajęczego mięsa. Choć przepis wydaje się krótki, wystarcza do zarysowania systemu wiedzy greckiego medyka. Nadto daje okazję do zaproponowania nowej hipotezy dotyczącej pełnej listy ingrediencji, a więc skutkuje nowym odczytaniem klasycznego tekstu.

\section{DULCE IUSCELLUM}

Przejdźmy teraz do fragmentu mówiącego o przyrządzaniu sosu do zająca ${ }^{27}$. Jest on częścią rozdziału 13 De observatione ciborum i brzmi ...in dulci piper habentem, parum cariofilum et gingiber, costo et spicanardi vel folio ${ }^{28}$. Antimus pisze w nim, że mięso tych zwierząt winno być spożywane in dulci... Choć przekaz jest nieco enigmatyczny, sugeruje on, iż przyrządzone ${ }^{29}$ lepores novelli podawać trzeba było wraz ze słodkim, płynnym dodatkiem aromatyzowanym przyprawami. Terminem, jakiego używa Antimus na określenie takiej części składowej dań złożonych, jest iuscellum $^{30}$. Użycie przyimka in z ablatiwem sugeruje, że mięso serwowano zanurzone we wzmiankowanym dodatku ${ }^{31}$ albo je w nim maczano ${ }^{32}$.

27 Sosy pelniły istotną funkcję w kuchni, modyfikując smak potraw. Por.: J. Solomon, The Apician Sauce - Ius Apicianum [w:] Food, s. 115-131; M. Kokoszko, Sosy w kuchni greckiej. Garum (үópos) i pochodne, „Vox Patrum” 2006, vol. 49, s. 289-298; idem, Historia kuchni antycznej i bizantyńskiej. Sos

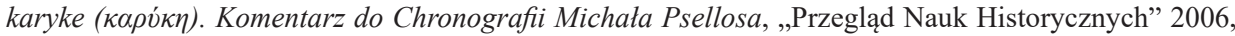
t. 5, nr 2 (10), s. 167-178.

${ }^{28}$ Antimus, 13, 5-6, p. 8. Bonnie Effros (op. cit., s. 64) oraz Grant (Intoduction, s. 28) uważają, że przyprawy te stanowiły zbiór rzadkich i kosztownych frykasów. Istnieją jednak świadectwa kontynuacji wymiany handlowej z Indiami, w tym także importu przypraw - C. Pion, B. Gratuze, P. Périn, T. Calligaro, Bead and Garnet Trade between the Merovingian, the Mediterranean, and Indian Worlds [w:] The Oxford Handbook of the Merovingian World, eds. B. Effros, I. Moreira, Oxford-New York 2020, s. 819, 833, 848-849; M. Bonifay, D. Pieri, Merovingian Gaul and the Mediterranean: Ceramics and Trade [w:] The Oxford Handbook, s. 871, 874.

${ }^{29}$ Autor milczy na temat metody przygotowania mięsa. Przedstawienie spójnej hipotezy dotyczącej technologii jego przyrządzenia wychodzi poza ramy niniejszych rozważań. W tym miejscu warto jedynie wspomnieć, że gdy chodzi o wołowinę, baraninę, jagnięcinę, koźlinę, mięso dzika i mięso bawołu, a więc pokarmy, które (podobnie jak zające) Galen (Loc. Aff., 183, 10-15, vol. VIII) klasyfikował jako produkty melancholiczne (z natury swej suche i zimne), Antimus zalecał ich gotowanie lub duszenie, to znaczy, że rekomendował tę samą metodę co Galen (w celu przydania im wilgoności i dodania im właściwości rozgrzewających, których pozbawiła ich natura). Proces ten mógł odbywać się w wodzie, ale

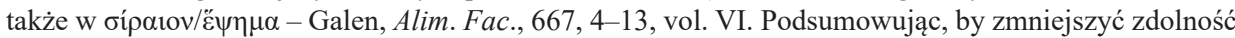
zajęczego mięsa do stymulowania produkcji czarnej żółci, najlepiej byłoby poddać je obróbce termicznej w płynie.

${ }^{30}$ Por. Antimus, 3, p. 5, 1; 4, p. 6, 1; 5, p. 6, 7; 10, p. 7, 8; 23, p. 12, 14; 24, p. 13, 2; 34, p. 16, 7.

${ }_{31}$ Pierwsza opcja ukazana została na przykład w rozdziale dotyczącym wołowiny, por. ibidem, 3 , p. 5,1 .

32 Druga opcja opisana została w rozdziale na temat podawania małych prosiąt (lactantes). Por. ibidem, 10, p. 7, 10. 
Z przepisu nie dowiadujemy się niczego na temat technologii sporządzania owego dulce iuscellum. Wypada domyślić się, że Antimus nie wprowadził detali do receptury z rozdziału 13, gdyż zasadnicze reguły przygotowywania sosów do mięs zostały sprecyzowane już wcześniej, to znaczy we fragmencie 3 De observatione ciborum, który dotyczył podawania wołowiny ${ }^{33}$. Zapewne lekarz wychodził z założenia, że szczegóły techniczne były znane kucharzom (również tym, którzy pracowali dla adresata jego dziełka, Teuderyka). Dlatego sam pisał tylko o kwestiach krytycznie ważnych z punktu widzenia zdrowia władcy Franków.

Antimus wymienia w swoim traktacie trzy substancje słodzące, które potencjalnie mogły znaleźć zastosowanie w przepisie, i określa je jako dulcedines ${ }^{34}$. Są to ...mel aut sapa aut carenum... ${ }^{35}$ Miód nie został w żaden sposób bliżej określony, a więc wnioskować wypada, że spośród licznych rodzajów opisywanych w literaturze medycznej i agronomicznej ${ }^{36}$ nie trzeba było wybierać tego produktu w zależności od jego właściwości implikowanych przez pochodzenie (na przykład nie musiał być to wyłącznie miód attycki ${ }^{37}$ ). O ile sapa i carenum/caroenum z pewnością były płynami, w których z łatwością można było gotować pokarmy, o tyle miód, z natury podlegający krystalizacji, może przyjmować konsystencję płynną albo stałą. Proces ten jesteśmy w stanie odwrócić poprzez poddanie miodu działaniu temperatury. Nie jest to jednak łatwe, gdyż miód szybko karmelizuje. Dlatego dobrze jest połączyć go z płynem, w którym rozpuści się w czasie podgrzewania. Problem ten nie trapił jednak kucharzy starożytności, ponieważ, jak dowiadujemy się z rozdziału na temat miodu zamieszczonego w De alimentorum facultatibus Galena (II/III w. n.e.) ${ }^{38}$, opisywany produkt był zwykle rozpuszczany w wodzie, a następnie gotowany. Celem tej procedury było usunięcie z niego piany (w której znajdowały się zanieczyszczenia),

${ }^{33}$ Na obowiązywanie w De observatione ciborum zasady referencji do wiedzy podanej wcześniej wskazuje na przykład przepis na dzika. Antimus odwołuje się w nim do informacji, które przekazał, omawiając baraninę: ...quomodo de uerbicinas indicauimus, por. ibidem, 8, p. 6, 15.

${ }^{34}$ Ibidem, 3, p. 5, 6 (...dulcedinem..). Środki słodzące w kuchni bizantyńskiej, por. J. Koder, Die Byzantiner, s. 233.

${ }^{35}$ Antimus, 3, p. 5, 13-14.

${ }^{36}$ Rola miodu w antyku i Bizancjum, por.: A. Dalby, Food in the Ancient World from A to Z, LondonNew York 2003, s. 179-180; P. Faas, Around the Roman Table. Food and Feasting in Ancient Rome,

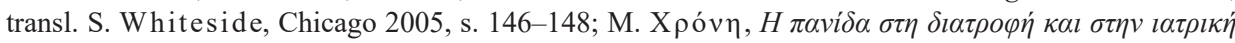

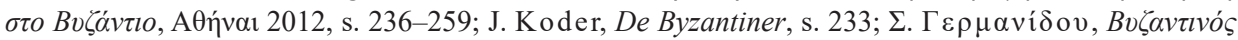

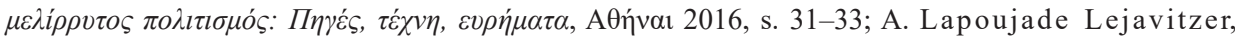
Dieta saludable, alimentos puros y purificación en el mundo grecolatino, „Nova Tellus. Revista semestral del Centro de Estudios Clásicos" 2016, vol. 34, no. 1, s. 113-117.

${ }^{37} \mathrm{Na}$ temat miodu attyckiego por.: Dioskurydes, II, 81, 1, 1-2; Galen, San. Tu., 342, 10-11, vol. VI etc. Pisał o nim też Diofanes (I w. p.n.e.; por. P. Thibodeau, Diophaness of Nikaia (85-60 BCE) [w:] The Encyclopedia, s. 267), a opinia ta została przytoczona w bizantyńskiej encyklopedii rolniczej z X wieku n.e. (Geoponica, XV, 7, 1), co sugeruje, że miód ten cieszył się doskonałą sławą przez wiele stuleci.

${ }^{38} \mathrm{Na}$ temat lekarza i jego dorobku por.: V. Boudon-Millot, Introduction générale [w:] Galien. Tome I: Introduction générale, Sur l'ordre de ses propres livres, Sur ses propres livres, Que l'excellent médecin est aussi philosophe, trad. V. Boudon-Millot, Paris 2007, s. VII-XC; S.P. Mattern, The Prince of Medicine: Galen in the Roman Empire, Oxford 2013, passim. 
co z punktu widzenia ówczesnej teorii materia medica powodowało zmianę charakterystyki pokarmu poprzez pozbawianie go typowej ostrości, która z kolei pobudzać miała wnętrzności do wydalania (co utrudniało przyswajanie pożywienia) ${ }^{39}$. Słowa Galena sugerują więc, iż przetwarzany w ten sposób miód zawierał pewną domieszkę wody, dzięki której zachowywał płynność i był mniej podatny na krystalizację.

Termin sapa oznaczał natomiast zredukowany moszcz winny ${ }^{40}$. Kolumella (I w. n.e.) pisał, że otrzymywano go, wygotowując wspomniany płyn do trzech czwartych, dwu trzecich albo też jednej drugiej jego pierwotnej objętości ${ }^{41}$. Pliniusz $(\mathrm{I} \text { w. n.e. })^{42}$ i Palladiusz (V w. n.e. $)^{43}$ przekazują, że gotowano go do jednej trzeciej pierwotnej objętości ${ }^{44}$, zwiększając w ten sposób procent zawartości cukru obecnego w soku z winogron, a także jego gęstość. Pliniusz dodał, że taki produkt z grecka określano jako siraeum lub hepsema (w oryginalnej wersji бípaıov ${ }^{45}$ lub Ě $\left.\psi \eta \mu \alpha^{46}\right)^{47}$. Wedle Palladiusza rzeczownik caroenum odnosił się do moszczu winnego zredukowanego do dwu trzecich jego pierwotnej objętości ${ }^{48}$. Odznaczał się zatem mniejszą zawartością cukru niż sapa i zawierał więcej wody. Być może był to jednak nie moszcz winny, ale zredukowane słodkie wino, przypominające w smaku trunek zwany oĩvo Kapúîvos, który to (ciemny, gęsty i bardzo słodki) produkowany był w Lidii. Był on wielokrotnie wzmiankowany przez Galena (i porównywany z oípaıvev) ${ }^{49}$. Choć terminy te nie są precyzyjnie zdefiniowane w literaturze antycznej, a zatem ich prawdziwe znaczenia budzą spory we współczesnej nauce, nie ma wątpliwości, iż odnosiły się do sui generis syropów o wysokiej, choć zróżnicowanej zawartości cukrów, a więc każdy z nich nadawał się do zastosowania w przepisie Antimusa. Skoro, jak wypada się domyśleć, oba produkty powszechnie wykorzystywano w kuchni, to zapewne lekarz miał z nimi styczność, a więc wiedział, czym różnią się między sobą. Nie musiał zatem rozwodzić się nad kwestią, która dla wszystkich była oczywista.

${ }^{39}$ Galen, Alim. Fac., 740, 10 - 741, 3, vol. VI.

${ }^{40} \mathrm{Na}$ temat sapa por.: A. Dalby, Food, s. 225; P. Faas, op. cit., s. 149.

${ }^{41}$ Kolumella, XII, 19, 1, 4-8. Na temat autora por.: R.H. Rodgers, L. Iunius Moderatus Columella of Gades (ca 40-ca 70 CE) [w:] The Encyclopedia, s. 456-457.

${ }^{42}$ Pliniusz, XIV, 80, 5-7. Na temat autora i jego encyklopedii por.: T. Murphy, Pliny the Elder's Natural History: The Empire in the Encyclopedia, Oxford-New York 2004, passim (zwłaszcza s. 1-48).

${ }^{43} \mathrm{Na}$ temat autora por.: R.H. Rodgers, Palladius Rutilius Taurus Aemilianus (ca 375-ca 450 CE) [w:] The Encyclopedia, s. 35-36.

${ }^{44}$ Palladiusz, XI, 18.

${ }^{45}$ Termin ten występuje w wielu pismach medycznych, na przykład por.: Dioskurydes, V, 6, 4, 4; Galen, Vict. At., 88, 1-89, 1; Galen, Alim. Fac., 503, 8, vol. VI; Orybazjusz, Coll., II, 61, 6, 3; Aecjusz, I, 227, 2; Paweł, I, 4, 1, 8 etc.

${ }_{46}$ Termin ten był używany w medycznej literaturze fachowej, por: Dioskurydes, V, 6, 4, 4; Galen, Alim. Fac., 503, 8, vol. VI; 667, 10, vol. VI; Orybazjusz, Coll., IV, 1, 21, 3; Aecjusz, III, 143, 8; Paweł, VII, 3, 5, 141 etc.

${ }^{47}$ Pliniusz, XIV, 80, 5-6.

${ }_{48}^{4}$ Palladiusz, XI, 18. Na temat carenum/caroenum por.: A. Dalby, Food, s. 224; P. Faas, op. cit., s. 148.

49 Por. np.: Galen, Vict. At., 98, 2-99, 1; Galen, Bon. Mal. Suc., 801, 2-6; Galen, Dig. Puls., 774, $16-775,5$, vol. VIII etc. 
Receptura Antimusa zawiera też przyprawy egzotyczne: pieprz (piper), goździki (cariofila), imbir (gingiber), kostus (czy też kostowiec), czyli putchuk (costus), oraz spicanardi vel folio ${ }^{50}$. Jeżeli posłużyć się analogią do danych zawartych w przepisie na wołowinę, rozdrabniano te składniki sosu w ceramicznym moździerzu z dodatkiem na przykład małej ilości wina ${ }^{51}$ (które było używane, by ułatwić rozcieranie i zapobiec pyleniu drobno roztartych przypraw). Tak wstępnie przygotowane ingrediencje łączono z miodem, sapa lub carenum/caroenum.

Antimus nic nie pisał o tym, czy sos był sporządzany na zimno, czy na gorąco. Technologia opisana $\mathrm{w}$ przepisie 3 , przepis na oxymeli ${ }^{52}$ (zawarty w rozdziale 10 dotyczącym podawania młodej wieprzowiny) ${ }^{53}$ oraz rozdział 24 (na temat przygotowywania pawi $)^{54}$ zachowane w De observatione ciborum skłaniają jednak do sugestii, iż sosy do mięsa powstawały zwykle na drodze gotowania ich składników. Taką metodę przyrządzania podpowiada też fakt, że obróbka cieplna tych dodatków była stosowana w przepisach na mięso zająca, które znajdujemy w De re coquinaria (IV w. n.e. $)^{55}$, co zostało wyraźnie zaznaczone w recepturach numer 1, 3, 4, 5, 6, 7, 9, 11, 12 i 13 księgi VIII rzeczonej kolekcji ${ }^{56}$. Podgrzewanie składników było istotne zwłaszcza wtedy, gdy do potrawy dodawano ingrediencje aromatyczne, gdyż, jak

${ }^{50}$ Mark Grant zaznacza, że przyprawy użyte do przygotowania wspomnianego sosu w Galii w VI wieku należały do rarytasów, por. M. Grant, Introduction, s. 28.

51 ista omnia simul trita bene in mortario fictile addito vino modico... - Antimus, 3, p. 5, 10-11.

52 Źródła medyczne wskazują, że oxymeli był otrzymywany wskutek gotowania wody, miodu i octu aż do uzyskania odpowiedniej konsystencji. Antimus pisze o tym procesie w słowach brzmiących: ...et sic coquat in vas fictile-Antimus, 10, p. 7, 12. Nie wspomina jednak wcale o wodzie jako o składniku tego dodatku. Teksty medyczne mówią o wielu wariantach recepturalnych, ale wszystkie potwierdzają informacje Antimusa na temat sporządzania oxymeli na gorąco. Por.: Dioskurydes, V, 14, 1, 1-4; Galen, San. Tu., 273, 11 - 274, 7, vol. VI; Orybazjusz, Coll., V, 24, 9, 1 - 15, 3; Orybazjusz, Lib., IV, 144, 4, 1 - 6, 2; Aecjusz, IX, 24, 101-113. Na temat oxymeli por.: M. X $\rho$ óv $\eta$, op. cit., s. 272-278; J. Koder, Die Byzantiner, s. 218-219.

53 Antimus, 10, p. 7, 8-13.

54 Ibidem, 24, p. 12, $17-13,5$.

${ }_{55} \mathrm{Na}$ temat De re coquinaria por.: Ch. Grocock, S. Grainger, Introduction [w:] Apicius: A Critical Edition with an Introduction and an English Translation of the Latin Recipe Text Apicius, Blackawton-Totnes 2006, s. 13-32; M. Kokoszko, Z. Rzeźnicka, K. Jagusiak, Health and Culinary Art in Antiquity and Early Byzantium in the Light of De re coquinaria, „Studia Ceranea” 2012, vol. 2, s. 145-164; I. Mikołajczyk, S. Wyszomirski, Wstęp [w:] Apicjusz, O sztuce kulinarnej ksiag dziesięć, tłum. I. Mikołajczyk, S. Wyszomirski, Toruń 2012, s. 3-13; A. Lejavitzer Lapoujade, Terminología culinaria en De re coquinaria: lengua técnica y coincidencias con el latín vulgar, „Nova Tellus. Revista semestral del Centro de Estudios Clásicos” 2020, vol. 38, no. 2, s. 83-86. Popularność De re coquinaria przekroczyła ramy antyku, por. B. Laurioux, Cuisiner à l'Antique: Apicius au Moyen Age, „Médiévales” 1994, vol. 26, s. 17-38. Zbiór ten był w czasach nowożytnych traktowany nie tylko jako kolekcja kulinarna, ale także zasób antycznych nauk z dziedziny medycyny, tj. z zakresu dietetyki i materia medica, por.: W. As fora Nadler, Collecting and Interpreting Apicius in Fifteenth-Century Italy Manuscript Tradition and Circulation of Culinary/Dietary Knowledge, „Food and History” (Tours) 2016, vol. 14, no. 2/3, s. 183-203.

${ }_{56}$ Apicjusz, VIII, 8, 1; VIII, 8, 3; VIII, 8, 4; VIII, 8, 5; VIII, 8, 6; VIII, 8, 7; VIII, 8, 9; VIII, 8, 11; VIII, 8, 12; VIII, 8, 13. 
zaznaczył Antimus w recepturze na wołowinę, ówcześni dietetycy i kucharze mieli świadomość, że temperatura wydobywała z przypraw ich aromat ${ }^{57}$.

Sos do zająca zwierał pieprz, który od przełomu VI i V wieku p.n.e. należał do ulubionych przypraw starożytności ${ }^{58}$. Był popularny, choć importowano go $\mathrm{z}$ dalekich krain (które nazywano Indiami ${ }^{59}$ ) i dlatego osiągał wysoką cenę. Pliniusz pisze, że najdroższy był pieprz długi, gdyż sprzedawano go za od 10 do 15 denarów za funt ${ }^{60}$, gdy biały kosztował od 7 do 10 , a czarny od 4 do 10 denarów ${ }^{61}$. Tak jak pozostałe substancje aromatyczne odnotowany on został w wykazie cen maksymalnych cesarza Dioklecjana. Dowiadujemy się z niego, że za funt pieprzu trzeba było zapłacić 800 denarów $^{62}$. Chociaż nie dysponujemy dokładnymi danymi na temat cen pieprzu w czasach Antimusa, to informacje zawarte w historii Teofylakta Symokatty ${ }^{63}$ (a potem także w kronice Teofanesa Wyznawcy ${ }^{64}$ ), dotyczące okresu walk cesarza Maurycjusza z Awarami (w czasie których Rzymianie zmuszeni zostali do przekazania swym przeciwnikom kontrybucji wypłaconej w naturaliach takich jak pieprz, $\varphi v ́ \lambda \lambda o v$

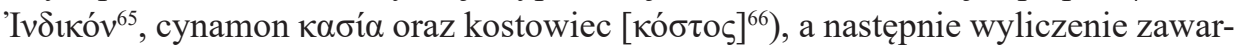
tości skarbca należącego do władcy Persów Chosroesa II (zdobytego przez wojska cesarza Herakliusza w roku 627, a zawierającego m.in. pieprz i imbir ${ }^{67}$ ), zachowane przez Teofanesa Wyznawcę $e^{68}$, pośrednio świadczą o znacznej wartości tej przyprawy pod koniec VI i w pierwszej połowie VII wieku. Barbarzyńcy bowiem nie przyjęliby okupu w naturaliach, gdyby nie były one dla nich przynajmniej tak samo cenne jak kruszec, a pieprz i imbir nie byłyby tezauryzowane przez Persów, gdyby nie uważali ich za dobra luksusowe. Dodajmy, że obie wzmianki nie zachowałyby się w dziełach bizantyńskich historyków, gdyby Teofylakt (na początku VII w. n.e.) i Teofanes (na

${ }^{57}$ Ista... trita...mittis in olla...ut antequam tollatur de foco, modicum sentiam et remittat in ius virtutem suam - Antimus, 3, p. 5, 10-13.

${ }_{58} \mathrm{Na}$ temat pieprzu por.: B. Laurioux, Spices in the Medieval Diet: A New Approach, „Food and Foodways: Explorations in the History and Culture of Human Nourishment" 1985, vol. 1, s. 43-75; A. Dalby, Siren Feasts: A History of Food and Gastronomy in Greece, London-New York 1996, s.137138; idem, Dangerous Tastes: The Story of Spices, London 2000, s. 90-94; idem, Empire of Pleasures: Luxury and Indulgence in the Roman Empire, London 2000, s. 194-196; idem, Food, s. 254-255; P. F a as, op. cit., s. 165-166; E. Lev, Z. A mar, Practical Materia Medica of the Medieval Eastern Mediterranean According to the Cairo Genizah, Leiden-Boston 2008, s. 236-239; M.A. Cobb, The Reception and Consumption of Eastern Goods in Roman Society, „Greece \& Rome” 2013, vol. 60, no. 1, s. 140-141; idem, Black Pepper Consumption in the Roman Empire, „Journal of the Economic and Social History of the Orient" 2018, vol. 61, no. 4, s. 519-559. Pieprz pozostawał cenną przyprawą kuchenną także w okresie średniowiecza - W. Heyd, Geschichte des Levantehandels im Mittelalter, vol. 2, Stuttgart 1879, s. 639-640.

59 Por. W. Heyd, op. cit., s. 635-639.

${ }^{60}$ Funt $=327 \mathrm{~g}$.

61 Pliniusz, XII, 28, $6-29,1$.

${ }^{62}$ Edictum Diocletiani, 36, 114 (Lauffer); 34, 67 (Reynolds).

${ }^{63}$ Teofylakt Symokatta, VII, 13, 6, 1-4.

${ }^{64}$ Teofanes, 278, 22-24.

${ }^{65}$ Por. rozważania na temat terminu folium zawarte w niniejszym studium.

${ }^{66}$ Por. rozważania na temat terminu costus zawarte w niniejszym studium.

${ }^{67}$ Por. rozważania na temat terminu gingiber zawarte w niniejszym studium.

68 Teofanes, 322, 5. 
początku IX w. n.e.) nie uznali wyliczonych przez siebie produktów za dobra warte wymienienia z powodu prestiżu, którym się cieszyły. Zarówno zatem historia spisana przez Teofylakta, jak i kronika pióra Teofanesa dowodzą, że pieprz należał do kosztownych produktów długo po okresie skomponowania De observatione ciborum przez Antimusa. Pieprz stosunkowo wcześnie stał się obiektem zainteresowania medyków. Nic dziwnego, że jego pierwsza pełna charakterystyka pojawia się wraz z początkiem dojrzałej wiedzy o substancjach leczniczych, którą reprezentuje dzieło Dioskurydesa (I w. n.e.) ${ }^{69}$. Autor wymienia trzy rodzaje pieprzu (to znaczy: długi, biały i czarny), przypisując każdemu z nich ostrość, dobry smak oraz potwierdzając ich zastosowanie w kuchni. Nadto określa on wszystkie warianty tej przyprawy jako substancje posiadające działanie rozgrzewające, diuretyczne, sprzyjające trawieniu, ściągające i diaforetyczne ${ }^{70}$. Pieprz pozostał obiektem zainteresowania wszystkich późniejszych lekarzy zajmujących się nim jako pokarmem i lekarstwem¹.

Goździki sprowadzano aż z Moluków. Pliniusz twierdził, że pochodzą z Indii ${ }^{72}$. O tym, że na trwałe były obecne w farmakopei Greków, świadczy fakt, że w VI wieku n.e. ich wykorzystywanie (jako składnika preparatów aromatycznych i leków) wzmiankowane jest przez Aecjusza z Amidy ${ }^{73}$ oraz Aleksandra z Tralles (VI/VII w. n.e. $)^{74}$. Pierwsza pełniejsza charakterystyka ich właściwości pochodzi jednak dopiero z VII wieku i zachowała się w encyklopedii medycznej Pawła z Eginy. Autor stwierdził, że pięknie pachną, są ostre, nieco gorzkawe, rozgrzewające i silnie

${ }^{69}$ Dioskurydes, II, 159, 1, 1 - 4, 3. Na temat autora i jego traktatu por.: J.M. Riddle, Dioscorides on Pharmacy and Medicine. Foreword by J. Sarborough, Austin 1985, passim (zwłaszcza s. 1-24); M. Kokoszko, K. Jagusiak, Z. Rzeźnicka, J. Dybała, Pedanius Dioscorides’ Remarks on Milk Properties, Quality and Processing Technology, „Journal of Archaeological Science: Reports” 2018, vol. 19, s. 982. Znaczenie traktatu Dioskurydesa dla bizantyńskiej materia medica por. A. Touwaide, Medicine and Pharmacy [w:] A Companion, s. 364-366, 376-377, 381-382.

70 Dioskurydes, II, 159, 1, 1 - 4, 8 (charakterystyki poszczególnych rodzajów - II, 159, 1, 6 - 2, 7; wspólne działania wszystkich rodzajów pieprzu - II, 159, 3, 1-2).

71 Galen zajmował się pieprzem jako pokarmem w De alimentorum facultatibus. Przypisał mu działanie rozgrzewające (Galen, Alim. Fac., 477, 5-9, vol. VI), tnące (ibidem, 570, 11 - 573, 9, vol. VI), rozcieńczające i oczyszczające (ibidem, 572, 6-12, vol. VI) oraz wspomagające trawienie (ibidem, 705, 9-13, vol. VI). Charakterystyka pieprzu jako lekarstwa (ostrość, działanie rozgrzewające i wysuszające) Galen, SMT, 97, 7 - 16, vol. XII. Medycyna bizantyńska o pieprzu - Orybazjusz, Coll., XII, $\pi$, 7, 1-12; XV, 1:16, 12, 1-15, 1 etc.); Aecjusz, I, 316, 1-5; Paweł, VII, 3, 16, 27-31 etc.

72 Pliniusz, XII, 30, 1-3. Na temat goździków por. W. Heyd, Geschichte, vol. 2, s. 593-597; B. Laurioux, Spices, s. 43-75; A. Dalby, Siren, s. 138-139; idem, Dangerous, s. 50-52; idem, Food, s. 89; P. Faas, op. cit., s. 165; A.-M. Talbot, Mealtime in Monasteries: The Culture of the Byzantine Refectory [w:] Eat, Drink, and Be Merry (Luke 12:19) - Food and Wine in Byzantium Papers of the 37th Annual Spring Symposium of Byzantine Studies, in Honour of Professor A.A.M. Bryer, eds. L. Brubaker, K. Linardou, Aldershot-Burlington, VT 2007, s. 118; E. Lev, Z. A mar, Practical, s. 151-153. Goździki w czasach Antimusa por. B. Laurioux, Spices, s. 62.

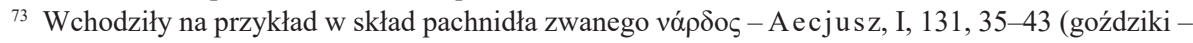
I, 131, 36).

${ }^{74} \mathrm{Na}$ przykład Aleksander, I, 611, 25 - 613, 5. Na temat lekarza por.: P. Bouras-Vallianatos, Clinical Experience in Late Antiquity: Alexander of Tralles and the Therapy of Epilepsy, „Medical History" 2014, vol. 58, no. 3, s. 337-353; idem, Galen in Late, s. 44-52; P. Kripouri, D. Filippou, On the Work of Alexander of Tralles, „Acta Medico-Historica Adriatica” 2019, vol. 17, 2, s. 295-304. 
wysuszające. Dodał też, że znajdują różnorakie zastosowanie zarówno w kuchni, jak i farmakologii ${ }^{75}$.

Imbir był bardzo popularną przyprawą i lekarstwem. W I wieku n.e. kosztował od 5 do 10 denarów za funt ${ }^{76}$, podczas gdy na początku IV wieku n.e. za librę ${ }^{77}$ suchego imbiru trzeba było zapłacić już 250 denarów $^{78}$. Wysoka cena i prestiż imbiru jako środka aromatycznego musiały utrzymywać się przez kolejne stulecia, gdyż przyprawa ta została odnotowana przez Teofanesa Wyznawcę jako jeden z łupów wojennych znalezionych w pałacu Chosroesa II w Dastargerd ${ }^{79}$. De materia medica Dioskurydesa wskazuje, że właściwości tej rośliny zostały dobrze opisane już w I wieku n.e. We wspomnianym dziele czytamy zatem, że imbir ma działanie rozgrzewające, delikatnie sprzyja zmiękczaniu przewodu pokarmowego (a zatem stymuluje trawienie i wydalanie), dobrze wpływa na żołądek, a jego działanie na organizm jest podobne do wpływu pieprzu ${ }^{80}$. Kwestią zastosowania imbiru w medycynie były zainteresowane również następne pokolenia lekarzy ${ }^{81}$.

Do aromatycznych przypaw importowanych z dalekich krain należał także kostowiec $^{82}$. Pliniusz pozostawił informację, że korzenie tej rośliny sprzedawano za 5 i pół denara za funt ${ }^{83}$, natomiast z Edyktu Dioklecjana wiemy, że libra kostowca kosztowała 250 denarów $^{84}$. O prestiżu, którym się cieszył, a zatem i o jego stosunkowo wysokiej cenie na przełomie VI i VII wieku świadczy fakt, że przyprawa ta

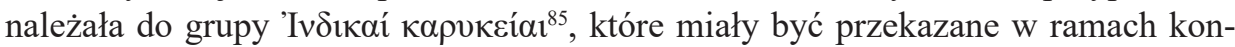
trybucji Awarom przez rzymskiego wodza Pryskusa ${ }^{86}$. Kostowiec był już dokładnie

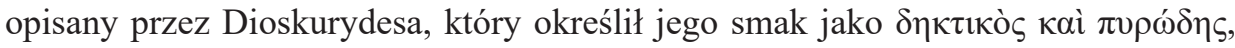
a zatem ostry i palący. Uważał on, że przyprawa ta charakteryzuje się działaniem rozgrzewającym i jest diuretyczna. Zapiski Galena oraz lekarzy wczesnego Bizancjum

75 Paweł, VII, 3, 10, 86-90.

76 Pliniusz, XII, 28, 6. Na temat imbiru por.: W. Heyd, op. cit., s. 600-604. B. Laurioux, Spices, s. 43-75; A. Dalby, Siren, s. 138; idem, Dangerous, s. 21-26; idem, Food, s. 159; P. Faas, op. cit., s. 164-165; E. Lev, Z. Amar, op. cit., s. 174-176.

77 Libra $=0,3271$.

78 Edictum Diocletiani, 36, 102 (Lauffer); 34, 56 (Craw ford, Reynolds).

79 Teofanes, 322, 6.

80 Dioskurydes, II, 160, 1, 1-12 (właściwości imbiru - II, 160, 1, 9-12).

${ }^{81}$ Galen, Alim. Fac., 572, 6-12; 703, 12 - 705, 14, vol. VI; idem, SMT, 880, 9 - 882, 4, vol. XI; Orybazjusz, Coll., XI, 丂, 2, 1-7; XV, 1:6, 1, 1-6, 1; Aecjusz z Amidy, I, 153, 1-4; Paweł, VII, $3,6,5-8$.

${ }^{82} \mathrm{Na}$ temat putchuk por.: W. Heyd, op. cit., s. 580-581; B. Laurioux, Spices, s. 63-64; A. Dalby, Dangerous, s. 85-86; idem, Empire, s. 197; idem, Food, s. 105; E. Lev, Z. A mar, op. cit., s. 157-158.

83 Pliniusz, XII, 41, 5-8.

${ }^{84}$ Edictum Diocletiani, 36, 47 (Lauffer); 34, 1 (Craw ford, Reynolds).

${ }^{85} \mathrm{Na}$ temat terminu каруквí $\alpha$ por. M. Kokoszko, Some Technical Terms from Greek Cuisine in Classical and Byzantine Literature, „Eos” 2008, vol. 95, s. 269-283.

${ }^{86}$ Teofylakt Symokatta, VII, 13, 5, 3-6, 5. Por. A. Dalby, Flavours of Byzantium, BlackawtonTotnes 2003, s. 43; idem, Tastes, s. 43. 
dowodzą, że opisywana roślina była również wykorzystywana w medycynie późniejszego okresu ${ }^{87}$.

Listę ingrediencji do sosu zamyka fraza spicanardi vel folio. Nardus, zwany

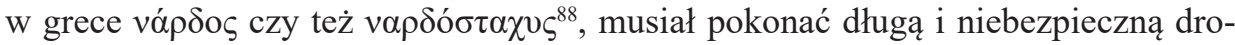
gę, zanim, urósłszy w Himalajach i Hindukuszu, przywieziony został do centrów cywilizacyjnych kultury grecko-rzymskiej. Pliniusz pisał, że cena jednego funta tak zwanych kłosów (spicae) nardu osiągała nawet 100 denarów, gdy najwyżej ceniony rodzaj jego liści nawet 90 denarów ${ }^{89}$. Chociaż w Edykcie Dioklecjana informacja o cenie nardu nie zachowała się, to skoro w tym samym źródle odnotowano, że libra olejku z tej rośliny kosztowała 75 denarów ${ }^{90}$, możemy zakładać, że na początku IV wieku n.e. nard w dalszym ciągu należał do cennych towarów. Dokładny opis właściwości nardu zawdzięczamy akrybii Dioskurydesa ${ }^{91}$. Jeśli chodzi o interesujące nas szczegóły, czytamy, że nard ma działanie rozgrzewające, wysuszające i diuretyczne ${ }^{92}$. Dlatego też pity doprowadza do spowolnienia pracy przewodu pokarmowego (skutkiem tego zmniejszenia biegunki) ${ }^{93}$. Nard podany w zimnej wodzie ${ }^{94}$ pomaga cierpiącym na nudności, zgagę, mającym gazy, chorym na wątrobę, trapionym przez żółtaczkę oraz problemy z nerkami ${ }^{95}$. Dodawany jest także do odtrutek ${ }^{96}$. Zapiski Galena i lekarzy wczesnego Bizancjum dowodzą, że również w późniejszych stuleciach nard z powodzeniem stosowany był w zabiegach terapeutycznych ${ }^{97}$.

Antimus kończy swą recepturę na sos, wprowadzając tekst brzmiący vel folio. Mark Grant, thumacz De observatione ciborum na język angielski, opierając się na wersji oryginału brzmiącej ...spicam nardi vel folium, interpretuje dwa ostatnie słowa jako odnoszące się do nardu, sugerując, iż w przepisie należało użyć albo tak zwanego kłosa nardu (spica) albo też jego liścia $(\text { folium })^{98}$, a wersję tę podtrzymuje

${ }^{87}$ Galen, SMT, 40, 10 - 41, 6, vol. XII; Orybazjusz, Coll., XI, к, 31, 1-9; XV, 1:10, 65, 1-3; Aecjusz, I, 219, 1-12; Paweł, VII, 3, 10, 306-315.

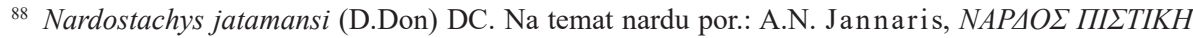
or 'SPIKENARD', „The Classical Review” 1902, vol. 16, no. 9, s. 459-460; W.H. Schoff, Nard, „Journal of the American Oriental Society” 1923, vol. 43, s. 216-228; F. Weberling, On the Systematics of Nardostachys, „Taxon” 1975, vol. 24, no. 4, s. 443-452; B. Laurioux, Spices, s. 45, 54, 62-64; A. Dalby, Dangerous, s. 86-88; idem, Empire, s. 196-197; E. Lev, Z. Amar, op. cit., s. 289-293; M. Kokoszko, Nard (vópdos; Nardostachys jatamansi [D. Don] DC) [w:] Lek roślinny, vol. VI, Rośliny w lecznictwie, w środowisku naturalnym i w krajobrazie kulturowym, red. B. Płonka-Syroka, A. Syroka, Wrocław 2017, s. 31-51.

89 Pliniusz, XII, 43, 6 - 44, 4.

${ }^{90}$ Edictum Diocletiani, 36, 98 (Lauffer); 34, 52 (Craw ford, Reynolds).

${ }^{91}$ Dioskurydes, I, 7, 1, 1-4, 9 .

${ }_{92}$ Ibidem, I, 7, 3, 9.

${ }_{93}$ Ibidem, I, 7, 3, 9-10.

${ }_{94}$ Autorowi chodzi zapewne o napar z nardu rozcieńczony zimną wodą.

${ }_{95}$ Dioskurydes, I, 7, 4, 1-3.

${ }^{96}$ Ibidem, I, 7, 4, 7.

${ }^{97}$ Galen, SMT, 84, 11 - 85, 3, vol. XII; Orybazjusz, Coll., XII, v, 1, 1-23; XV, 1:13, 1, 1 - 2, 1; Aecjusz, I, 289, 1-8; Paweł, VII, 3, 13, 5-9.

${ }_{98}$ Antimus, On the Observance of Foods. De observatione ciborum, ed., transl. M. Grant, Blackawton-Totnes 2007, s. 55. 
też Deroux ${ }^{99}$ oraz Liechtenhan ${ }^{100}$. Sugestia ta zresztą idzie śladami uwag Valentina Rose'a, który w słowniku ${ }^{101}$ do wydania dzieła Antimusa wychodził z tego samego założenia. W ten sposób sugerują oni, że przydawka dopełniaczowa nardi odnosi się zarówno do rzeczownika spica, jak i folio/folium ${ }^{102}$. Istnieje wszakże też druga możliwość rozumienia tego samego fragmentu dzieła Antimusa, a mianowicie rzeczownik foliolfolium winien być interpretowany jako niezależny fitonim, który jest $\mathrm{w}$ istocie swej pars pro toto, gdyż ukuty został od tej części rośliny, która używana była do celów kulinarnych albo terapeutycznych.

W zachowanych źródłach odnajdujemy przekonujące dowody na istnienie takiej rośliny. Pierwszy stanowi dorobek Galena w połączeniu z Eclogae medicamentorum $^{103}$. Galen cytował receptę na lekarstwo Polyarcha (I w. p.n.e./I w. n.e. ${ }^{104}$ ), która obejmowała $\varphi v ́ \lambda \lambda \alpha \mu \alpha \lambda \alpha \beta \alpha \theta \rho \rho v^{105}$, czyli tejpat (a zatem liście cynamonowca

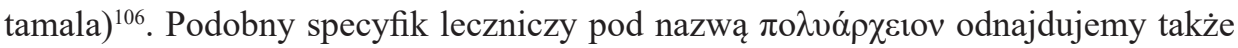
w Eclogae medicamentorum, ale w formule owego leku autor uwzględnił jedynie ter$\min \varphi v ́ \lambda \lambda o v^{107}$. Ponieważ składniki oraz przeznaczenie jednego i drugiego leku są analogiczne, nie ma wątpliwości, iż obu autorom chodziło o ten sam medykament. Zatem

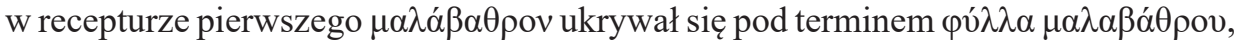
to znaczy „liście $\mu \alpha \lambda \alpha ́ \beta \alpha \theta \rho o v ”$, podczas gdy u drugiego został nazwany po prostu $\varphi v ́ \lambda \lambda o v$, a więc „liść”. Drugie exemplum stanowi dorobek Aecjusza z Amidy. Wśród opisanych przez niego olejków zapachowych natykamy się także na taki, który zwany

99 C. Deroux, Anthime, s. 1111.

100 E. Liechtenhan, op. cit., s. 37.

101 Anthimi De observatione ciborum epistula ad Teudericum regem Francorum, ed. V. Rose, Lipsiae 1877, s. 52 s.v. folium.

102 Wypada zaznaczyć, że wersja tekstu promowana przez Liechtehana pozbawiona jest przydawki dopełniaczowej do folio i dlatego termin ten staje się oddzielnym desygnatem.

103 Eclogae medicamentorum jest dziełem anonimowym, choć przypisywanym Orybazjuszowi. Argumenty za jego autorstwem przedstawiła ostatnio Antonella P as s abì (Dagli scritti di Oribasio: l'uso

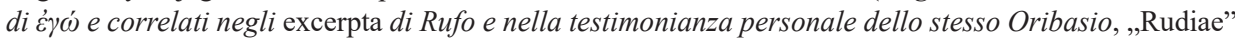
[Salento] 2007, vol. 19, s. 71-138). Podsumowanie dyskusji na temat autorstwa Eclogae medicamentorum, por.: S. Buzzi, La "forma breve" come paradigma compositivo nella produzione scientifica di epoca tardoantica: il caso di Oribasio [w:] Forma breve, eds. D. Borgogni, G.P. Caprettini, C. Vaglio Marengo, Torino 2016, s. 195, przypis 8; eadem, Polemica e controversia nel Corpus Oribasianum, „Medicina nei Secoli” 2017, 29, no. 3, s. 965, przypis 17; S. Buzzi, I. Calà, Le ricette cosmetiche nell' enciclopedie mediche tardoantiche [w:] Collecting Recipes. Byzantine and Jewish Pharmacology in Dialogue, eds. L. Lehmhaus, M. Martelli, Boston-Berlin 2017, s. 126, przypis 12.

104 P.T. Keyser, Poluarkhos (30 BCE-35 CE) [w:] The Encyclopedia, s. 680.

105 Galen, Comp. Med. Loc., 185, 8 - 186, 8, vol. XIII ( $\mu \alpha \lambda \alpha ́ \beta \alpha \theta \rho o v-185,16$, vol. XIII).

106 Cinnamomum tamala (Buch.-Ham.) T. Nees \& Eberm. Na temat tejpat por.: A. Dalby, Empire, s. 198-199; idem, Dangerous, s. 41-46; idem, Food, s. 206; E. Lev, Z. Amar, op. cit., s. 444-445; M. Kokoszko, Z. Rzeźnicka, Malábathron ( $\mu \alpha \lambda \alpha \dot{\beta} \alpha \theta \rho o v)$. Kilka uwag o roli Cinnamomum tamala $w$ kuchni $i$ medycynie antyku $i$ Bizancjum w okresie pomiędzy I a VII wiekiem, „Przegląd Nauk

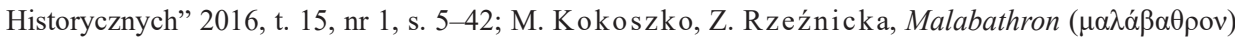
in Ancient and Early Byzantine Medicine and Cuisine, „Medicina nei Secoli” 2018, vol. 30, no. 2, s. 579-616.

107 Eclogae medicamentorum, 51, 8, 1-9, 1 ( 


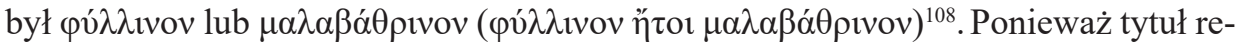
ceptury wskazuje na tożsamość terminów pú $\lambda \lambda$ ivov oraz $\mu \alpha \lambda \alpha \beta \alpha \dot{\theta} \theta \rho ı v o v$, wnioskować wypada, że nazwa tego olejku ukuta została od użytego w recepcie rzeczownika $\varphi v ́ \lambda \lambda \mathrm{ov}^{109}$, który w tym przypadku oznaczał bez wątpienia liść $\mu \alpha \lambda \alpha \dot{\beta} \alpha \theta \rho \rho \mathrm{v}$, co z kolei znalazło odbicie w alternatywnej nazwie (to znaczy $\mu \alpha \lambda \alpha \beta a ́ \theta \rho ı v o v)$ używanej na oznaczenie tego samego pachnidła.

Dodajmy, że termin folium występuje też w De re coquinaria ${ }^{110}$. W trzech recepturach rzeczowniki folium i malabathrum pojawiają się jednak obok siebie ${ }^{111}$, co może sugerować, iż oba mają oddzielne desygnaty. Jest jednak wiele argumentów, które wskazują, że należy uznać wszystkie receptury z De re coquinaria, które zawierają termin folium, za przepisy odnoszące się do użycia malabathrum, czyli tejpat. Weźmy pod uwagę chociażby dwie przesłanki, zaczynając od księgi I, a dokładniej od win. Istotną grupę wśród trunków opisywanych w literaturze antycznej i bizantyń-

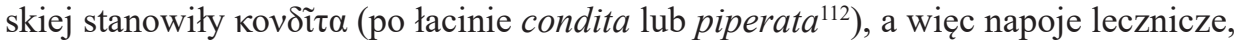
w skład których wchodziły zwykle pieprz, miód oraz cała lista innych składników.

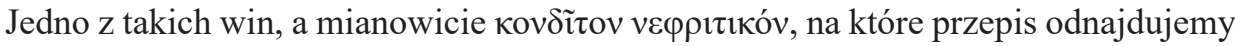
w Eclogae medicamentorum ${ }^{113}$, ma swój odpowiednik w conditum paradoxum, którego receptura cytowana jest $\mathrm{w}$ księdze I zbioru przypisywanego Apicjuszowi ${ }^{114}$. Oba zawierają rzeczowniki oznaczające „liść”, brzmiące odpowiednio po łacinie folium, a po grecku $\varphi v ́ \lambda \lambda o v$. Ponieważ, jak już ustaliliśmy, autor Eclogae medicamentorum rozumiał pod tym terminem roślinę zwaną przez Greków $\mu \alpha \lambda \alpha \dot{\beta} \beta \alpha \theta \rho o v$, istnieje duże prawdopodobieństwo, że ta sama przyprawa kryła się także za rzeczownikiem użytym w łacińskim tekście De re coquinaria. Notabene interpretację tę uprawdopodabnia uwaga Pliniusza, który expressis verbis pisał o znakomitych efektach dodawania malobathrum do wina ${ }^{115}$. Drugim przykładem niech będzie apsintium Romanum, na które przepis również odnajdujemy w księdze I De re coquinaria ${ }^{116}$ i które ma swój

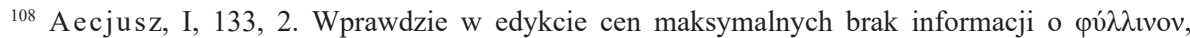
ale $\mathrm{w}$ rozdziale na temat cen substancji aromatycznych wyszczególniona została wonna maść zwana

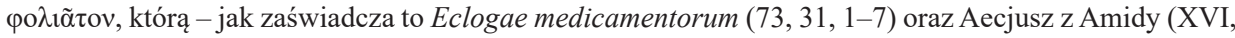
131, 4-17) - przygotowywano z dodatkiem tejpat. Trzeba wszakże dodać, że źródła wymieniają także inne pachnidło o tej samej nazwie, które nie uwzględniało w swej recepturze cynamonowca tamala. Wzmiankowane jest ono wielokrotnie przez Galena (San. Tu., 427, 3-5, vol. VI etc.). Jego alternatywna

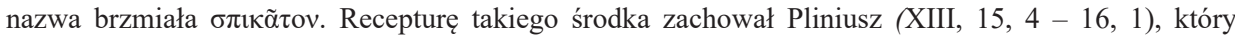
nazywa go również nardinum. Aecjusz z Amidy zachował szereg podobnych receptur - Aecjusz, XVI,

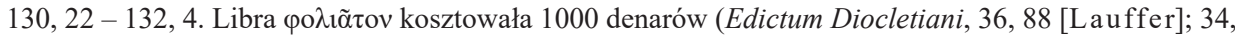
42 [Crawford, Reynolds]), natomiast taka sama ilość niemytych liści tejpat - 60 denarów (Edictum Diocletiani, 36, 49 [Lauffer]; 34, 3 [Crawford, Reynolds]).

${ }_{109}$ Recepta nie wymienia terminu $\mu \alpha \lambda \alpha \dot{\beta} \beta \alpha \rho \rho$.

${ }_{110}$ Apicjusz, I, 1; I, 3; I, 27; I, 29; VI, 5, 4; VII, 6, 8; VIII, 2, 6; IX, 1, 3; IX 7; IX, 8, 2; IX, 8, 3.

111 Ibidem, I, 29; IX, 1, 3; IX 7.

112 Pliniusz, XIV, 108, 2-3.

${ }^{113}$ Eclogae medicamentorum, 62, 8, 1-9, 1 (liść - 62, 8, 6) .

${ }_{114}$ Apicjusz, I, 1.

115 Por. cytowany wcześniej fragment Historia naturalis.

116 Apicjusz, I, 3. 
odpowiednik w ả $\psi \imath v \theta \alpha ́ \tau \alpha ~ O r y b a z j u s z a{ }^{117}$ i Aecjusza z Amidy ${ }^{118}$. W tym przypadku także łaciński termin folium występuje jako odpowiednik greckiego $\varphi v ́ \lambda \lambda o v$.

Konkludując, wypada postawić tezę, że skoro termin folium oznaczał liść $\mu \alpha \lambda \alpha ́ \beta \alpha \theta \rho o v$ w recepturach na wino, to samo znaczenie miał także w pozostałych przepisach zawartych w De re coquinaria, a pojawienie się zarówno słowa folium, jak i słowa malabathrum w księgach I i IX tego zbioru jest niczym innym jak błędem kopisty ${ }^{119}$. Jeśli więc rzeczownik folium w De re coquinaria oraz termin $\varphi v ́ \lambda \lambda$ ov w greckich traktatach medycznych oznacza liście tejpat, nie ma powodu, by miał on inne znaczenie w dziełku Antimusa, którego teoria materia medica była tożsama $\mathrm{z}$ występującą w tradycji medycznej tego okresu. Trzeba dodać, że ten punkt widzenia jest zgodny z poglądem Andrew Dalby'ego, który, choć nie przeprowadził dowodu na taką interpretację, w swych pracach konsekwentnie tłumaczy łaciński termin folium oraz grecki $\varphi v ́ \lambda \lambda$ ov jako tożsamy z malabathrum ${ }^{120}$.

Źródła medyczne eksplikują nam też, dlaczego Antimus zastosował w swej narracji spójnik vel. By to zrozumieć, sięgnijmy do zachowanych opisów właściwości tejpat. Mianowicie już w dorobku Dioskurydesa występuje wskazanie na bliskie pokrewieństwo, a nawet analogiczne działanie nardu i cynamonowca tamala. Autor pisze bowiem, iż ten drugi charakteryzuje się takimi samymi właściwościami jak nard indyjski, intensyfikując działanie innych substancji leczniczych. Zaznacza jednak, że jest on od nardu bardziej diuretyczny i lepszy dla żołądka, a nadto wskazuje na jego właściwości aromatyczne (pisząc, iż podkłada się tejpat pod język, by uczynić oddech przyjemnym ${ }^{121}$. Galen z kolei wprost wyszczególnił liście cynamonowca tamala jako zamiennik nardu. Uczynił to w De simplicium medicamentorum temperamentis ac facultatibus, stwierdzając, że roślina ta ma działanie analogiczne do tego, jakie przypisywane jest nardowi ${ }^{122}$. Późniejsze charakterystyki tejpat nie różnią się od ustaleń z przełomu I i II wieku n.e. ${ }^{123}$, na co wskazują informacje przekazane przez Orybazjusza ${ }^{124}$, Aecjusza z Amidy ${ }^{125}$ oraz Pawła z Eginy ${ }^{126}$. Konkludując, wypada

117 Orybazjusz, Coll., V, 33, 13, 1-5 (liść - V, 33, 13, 2).

${ }^{118}$ Aecjusz, III, 71, 1-4 (liść - III, 71, 1); III, 72, 1-3 (liść - III, 72, 2).

119 Zabiegu tego nie powtórzył, emendując tekst oryginału, autor Excerpta Vinidarii. Por. Ch. Grocock, S. Grainger, Appendix: A Glossary to Apicius [w:] Apicius, s. 347.

120 A. Dalby, Siren, s. 192, 306; idem, Food, s. 206; idem, Tastes, s. 175, 182 etc.

${ }^{121}$ Dioskurydes, I, 12, 1, 1-2, 11.

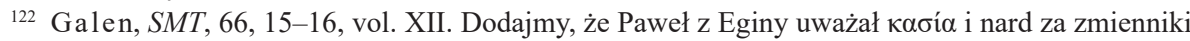
$\mu \alpha \lambda \alpha ́ \beta \alpha \theta \rho o v$ - Paweł, VII, 25, 12, 1.

${ }^{123}$ Niezgodności dotyczyły szczegółów: właściwości rozgrzewające określano jako pierwszy (por. Orybazjusz, Coll., XIV, 15, 1, 3; idem, Syn., II, 3, 1, 2; idem, Lib., II, 3, 1, 5-6; Aecjusz, II, 199, 2) lub trzeci stopień (Aecjusz, II, 201, 7). Wszyscy natomiast zgadzali się co do drugiego stopnia jego właściwości wysuszających - Orybazjusz, Coll., XIV, 26, 1, 6; idem, Lib., II, 5, 2, 6; Aecjusz, II, $211,7$.

${ }^{124}$ Główna charakterystyka $\mu \alpha \lambda \alpha ́ \beta \alpha \theta \rho o v$ obecna w Collectiones medicae Orybazjusza jest zapożyczona z De materia medica Dioskurydesa - Orybazjusz, Coll., XI, $\mu, 2$, 1-7. Por. idem, Synopsis ad Eustathium filum, II, 56, 35, 1 - 36, 1 ( $\mu \alpha \lambda \alpha ́ \beta \alpha \theta \rho o v$ - II, 56, 35, 1-2). Orybazjusz uwzględnił też uwagę Galena o podobieństwie działań $\mu \alpha \lambda \dot{\beta} \beta \alpha \theta \rho o v$ i nardu - idem, Coll., XV, 1:12, 2, 1-2.

${ }^{125}$ Aecjusz, I, 266, 1; II, 196, 64-68.

126 Paweł, VII, 3, 12, 6. 
stwierdzić, że Antimus, idąc za teorią materia medica na temat tejpat, radził w swym dziele, by do sosu do zająca użyć albo nardu, albo jego zamiennika, a zatem liści cynamonowca tamala. Uczynił tak z powodu analogicznych właściwości obu przypraw.

I jeszcze jedna kwestia. Sos do zająca zawiera substancje charakteryzujące się słodkim, ostrym oraz gorzkim smakiem. Z punktu widzenia teorii dietetycznej zastosowanie ich miało swoje uzasadnienie. Ponieważ mięso wymienione w przepisie Antimusa było klasyfikowane jako z natury twarde, a więc ciężkostrawne i przyczyniające się do produkcji w organizmie soków gęstych i lepkich, a zwłaszcza czarnej żółci (która z natury była sucha i zimna) ${ }^{127}$, trzeba było podać ten przysmak z dodatkami mającymi potencjał przeciwdziałania jego ewentualnemu negatywnemu wpływowi na organizm. Z punktu widzenia dietetyki logiczne było zaserwowanie zająca z sosem zawierającym miód, sapa czy carenum/caroenum, ponieważ wedle obowiązującej teorii pokarmy te miały właściwości rozgrzewające ${ }^{128}$. Oznacza to, że nie tylko zapewniały odpowiednią temperaturę żołądka (potrzebną do strawienia pożywienia) ${ }^{129}$, ale także zapobiegały wyziębieniu organizmu (które przynosiło ze sobą powstanie czarnej żółci). Wedle teorii dietetycznej płynność sosu oraz zastosowanie odpowiedniej technologii przygotowania samego mięsa zmniejszałyby też prawdopodobieństwo wysuszenia organizmu jedzącego ${ }^{130}$. Spośród wymienionych substancji słodzących najlepszy w tym celu byłby miód, uznawany nie tylko za rozgrzewający, diaforetyczny, ale też, dzięki swej ostrości, za oczyszczający. Choć w wyniku gotowania tracił nieco z tych dwu ostatnich właściwości, działanie to było nadal efektywne. Galen oceniał go jako dobry dla żołądka, co oznaczało, że tak jak inne słodkie ingrediencje przyczyniał się do właściwej pracy systemu trawiennego ${ }^{131}$. Słodkie składniki, jako substancje o drobnych cząstkach (określane przez Galena jako $\lambda \varepsilon \pi \tau o \mu \varepsilon \rho \tilde{\eta}^{132}$ ), a zatem sprzyjające rozkładaniu tego, co ma przeciwną naturę (tego, co w języku Galena klasyfikowane jest jako $\pi \alpha \chi v \mu \varepsilon \rho \tilde{\eta}^{133}$ ), rozrzedzały humory gęste i lepkie, a zwłaszcza ten, który zwany był czarną żółcią. Ich działanie było wzmocnione dzięki zastosowaniu przypraw o analogicznym wpływie na proces trawienia, choć o odmiennej charakterystyce smakowej. Wszystkim im przypisana

${ }^{127}$ Na temat właściwości zajęczego mięsa por.: De diaeta II, 46, 25-26; Galen, Alim. Fac., 664, 4-6, vol. VI; idem, Loc. Aff., 183, 13-14, vol. VIII; Orybazjusz, Coll., II, 28, 10, 1 - 12, 1; III, 16, 4, 1 - 6, 1; A ecjusz, II, 121, 25-18; II, 253, 8-10; Paweł, I, 84, 1, 7-9 etc. Na temat soków organicznych, które mogły potencjalnie przerodzić się w czarną żółć, por. K.A. Stewart, Galen's Theory of Black Bile: Hippocratic Tradition, Manipulation, Innovation, Leiden-Boston 2019, s. 75-93. Katalog schorzeń spowodowanych przez ten humor był długi. Lekarz zaliczał do nich zarazę przypadającą na czasy Marka Aureliusza, słoniowaciznę, owrzodzenia, nowotwory, hemoroidy i żylaki - Galen, At. Bil., 114, 9 119, 12, vol. V. Do wymienionych wypada dodać melancholię (idem, Loc. Aff., 179, 18 - 193, 6, vol. VIII), oraz gorączkę zwaną czwartaczką - idem, Diff. Feb., 336, 11-12; 343, 11 - 347, 3, vol. VII, etc. Por. K.A. Stewart, op. cit., s. 129-144.

128 Galen, SMT, 646, 2-5; 785, 6-7, vol. XI.

129 Ibidem, 786, 6-7, vol. XI.

130 Por. uwagi na temat techniki przyrządzania zajęczego mięsa zamieszczone w niniejszym studium.

131 Galen, SMT, 70, 13 - 71, 19, vol. XII.

132 Ibidem, 698, 4-10, vol. XII.

133 Galen, At. Bil., 111, 5-10, vol. V. 
była ostrość ${ }^{134}$ lub gorycz (i ostrość) ${ }^{135}$, które zdradzały ich zdolności rozgrzewające, i $\lambda \varepsilon \pi \tau \circ \mu \varepsilon \dot{\varepsilon} \rho \varepsilon 1 \alpha^{136}$.

Warto ponadto zwrócić uwagę na jeszcze jeden aspekt przepisu. Wszystkie przyprawy użyte do sporządzenia sosu były substancjami aromatycznymi, a zatem oprócz działania terapeutycznego miały wykwintny zapach, który z punktu widzenie dietetyki był cechą pożądaną, ale niekonieczną dla ostatecznego efektu terapeutycznego. Ponieważ wszystkie należały do towarów importowanych i kosztowały znaczne sumy, użycie jednej z nich czyniło danie wykwintnym, co być może Antimus zaznaczył, posługując się spójnikiem vel, a zatem pozwalając kucharzowi na wybór między drogim nardem a nieco tańszym tejpat. W sumie jednak zastosowanie w jednej recepturze pieprzu, goździków, kostowca i nardu lub pieprzu, goździków, kostowca, nardu i cynamonowca tamala sugeruje, że na zdrowy dodatek do mięsa zajęczego stać było jedynie elitę społeczeństwa Franków, która zaczynała już być na tyle wyrafinowana, że troszczyła się nie tylko o zaspokojenie swego głodu, ale także o miłe doznania dla swoich podniebień i nosów.

\section{KONKLUZJE}

Powyższe rozważania prowadzą do wniosku, że z pozoru uproszczony wykład Antimusa na temat przyrządzania pokarmów dla władcy Franków Teuderyka jest w efekcie oparty na szczegółowej wiedzy medycznej z zakresu dietetyki i materia medica. By go skonstruować, Antimus musiał posiadać rozległe kompetencje w zakresie antycznych teorii medycznych. Zauważmy jednak, że jego fachowość w tym zakresie łączy się ze znajomością ówczesnych praktyk kulinarnych.

Istnieje duże prawdopodobieństwo, że należy uzupełnić listę ingrediencji zastosowanych w sosie do zająca o tejpat. Fakt ten, jak dotąd, uchodził uwadze interpretatorów tekstu Antimusa, choć zachowana literatura medyczna bogata jest w świadectwa wspierające wnioski zaprezentowane w niniejszym studium.

Ponieważ rozdział 25 De observatione ciborum zawiera również wzmiankę o prowadzeniu przez autora tego dziełka praktyki lekarskiej, wnosić wypada, że list do Teuderyka nie był jedynie odwzorowaniem teorii znanej Antimusowi, ale także podsumowaniem doświadczeń praktycznych, jakie zebrał, lecząc pacjentów. Jeżeli tak, jego zachowany dorobek sugeruje, iż był on kompetentnym lekarzem, który wzorem Galena swoje nauki wzbogacił doświadczeniem ( $\dot{\varepsilon} \mu \pi \varepsilon \iota p i ́ \alpha)$ nabytym w leczeniu konkretnych przypadków chorobowych, a wskutek tego De observatione ciborum nie jest dziełem teoretyka medycyny, jakimi wcześniej byli Difilos z Sifnos (III w.

${ }^{134}$ Idem, SMT, 670, 12-14; 679, 10 - 680, 3, vol. XI. Por. ibidem, 785, 4-5; 785, 13-16, vol. XI.

${ }_{135}$ Ibidem, 646, 9-11, vol. XI; działanie substancji gorzkich - ibidem, 684, 4-7; 785, 2-3; 785, 17 - 786, 1, vol. XI.

${ }^{136}$ Ibidem, 653, $1-656,2$, vol. XI. 
p.n.e. $)^{137}$, a potem Symeon Seth (X/XI w. n.e.) ${ }^{138}$ i Michał Psellos (X/XI w. n.e.) ${ }^{139}$, ale praktykującego medyka, który wiedzę lekarzy antyku zaadaptował do wyzwań swoich czasów.

\section{BIBLIOGRAFIA}

\section{Źródła}

Aecjusz, Aetii Amideni Libri medicinales I-VIII, ed. A. Olivieri, Lipsiae-Berolini 19351950.

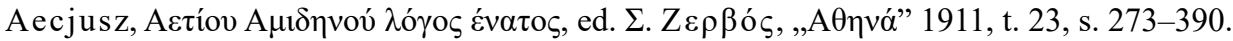

Aleksander, Alexandri Traliani Therapeutica [w:] Alexander von Tralles, ed. T. Puschmann, vol. I-II, Vienna 1878-1879.

Anthimus, On the Observance of Foods. De observatione ciborum, ed., transl. M. Grant, Blackawton-Totnes 2007.

Antimus, Anthimi De observatione ciborum epistula ad Teudericum regem Francorum, ed. V. Rose, Lipsiae 1877.

Antimus, Anthimi De observatione ciborum ad Theodoricum regem Francorum epistula, iteratis curis edidit et in linguam Germanicam transtulit E. Liechtenhan, Berlin 1963 (tekst referencyjny).

Apicius. A Critical Edition with an Introduction and an English Translation of the Latin Recipe Text Apicius, ed. Ch. Grocock, S. Grainger, Blackawton-Totnes 2006.

Apicjusz, O sztuce kulinarnej ksiag dziesięć, tłum. I. Mikołajczyk, S. Wyszomirski, Toruń 2012.

Dioskurydes, Pedanii Dioscuridis Anazarbei De materia medica libri V, ed. M. Wellmann, vol. I-III, Berolini 1906-1914.

Edictum Diocletiani et Collegarum de pretiis rerum venalium, ed. M. Giacchero, vol. I-II, Genova 1974.

Edictum Diocletiani de pretiis rerum venalum. Edykt Dioklecjana o cenach towarów wystawionych na sprzedaż, wstęp, thum., red. A. i P. Barańscy, P. Janiszewski, Poznań 2007.

Galen, Galeni De alimentorum facultatibus libri III [w:] Claudii Galeni Opera omnia, ed. C.G. Kühn, vol. VI, Lipsiae 1823 [Alim. Fac.].

Galen, Galeni De atra bile [w:] Claudii Galeni Opera omnia, ed. C.G. Kühn, vol. V, Lipsiae 1823 [At.Bil.].

${ }^{137}$ Por. J. Scarborough, Diphilus of Siphnos and Hellenistic Medical Dietetics, „Journal of the History of Medicine and Allied Sciences” 1970, vol. 25, no. 2, s. 194-201 (zwłaszcza s. 195-197).

138 Por.: P. Bouras-Vallianatos, Galen's Reception in Byzantium: Symeon Seth and his Refutation of Galenic Theories on Human Physiology, "Greek Roman and Byzantine Studies” 2015, vol. 55, s. 436-457 (zwłaszcza s. 442, 447); idem, Galen in Byzantine Medical Literature [w:] Brill's Companion to The Reception of Galen, eds. P. Bouras-Vallianatos, B. Zipser, Leiden-Boston 2019, s. 98.

139 Por.: A. Hohlweg, Medizinischer 'Enzyklopädismus' und das ПONHMA IATPIKON des Michael Psellos, „Byzantinische Zeitschrift” 1988, vol. 81, s. 39-49; P. Bouras-Vallianatos, Galen's Reception, s. 439, 443 (przypis 40), 446 (przypis 55), 447; idem, Galen in Byzantine, s. 97; I. Prérez Martín, D. Manolova, Science Teaching and Learning Methods in Byzantium [w:] A Companion, s. 68. 
Galen, Galeni De compositione medicamentorum secundum locos libri X [w:] Claudii Galeni Opera omnia, ed. C.G. Kühn, vol. XII-XIII, Lipsiae 1826-1827 [Comp. Med. Loc.].

Galen, Galeni De dignoscendis pulsibus libri IV [w:] Claudii Galeni Opera omnia, ed. C.G. Kühn, vol. VIII, Lipsiae 1824 [Dig. Puls.].

Galen, Galeni De febrium differentiis libri II [w:] Claudii Galeni Opera omnia, ed. C.G. Kühn, vol. V, Lipsiae 1823 [Diff. Feb.].

Galen, Galeni De locis affectis libri VI [w:] Claudii Galeni Opera omnia, ed. C.G. Kühn, vol. VIII, Lipsiae 1824 [Loc. Aff.].

Galen, Galeni De rebus boni malique suci libellus, ed. G. Helmreich, Lipsiae 1923 [Bon. Mal. Suc.].

Galen, Galeni De sanitate tuenda libri VI, [w:] Claudii Galeni Opera omnia, ed. C.G. Kühn, vol. VI, Lipsiae 1823 [San.Tu.].

Galen, Galeni De simplicium medicamentorum temperamentis ac facultatibus libri XI, [w:] Claudii Galeni Opera omnia, ed. C.G. Kühn, vol. XI-XII, Lipsiae 1826-1827 [SMT].

Galen, Galeni De victu attenuante, ed. K. Kalbfleisch, Lipsiae-Berlolini 1923 [Vict. At.]. Geoponica, ed. H. Beckh, Lipsiae 1895.

Geoponika. Farm Work: A Modern Translation of the Roman and Byzantine Farming Book, transl. A. Dalby, Blackawton-Totnes 2011.

Hippocratis De diaeta, ed., trans., comm., R. Joly, S. Byl, Berlin 2003.

Kassianus Bassus, Geoponika: bizantyńska encyklopedia rolnicza, tłum. I. Mikołajczyk, Toruń 2012.

Kolumella, L. Iuni Moderati Columellae De re rustica [w:] L. Iuni Moderati Columellae Opera quae exstant, ed. S. Hedberg, vol. VIII, Uppsala 1958.

Malchus, Exc. de Leg. Gent. [w:] The Fragmentary Classicising Historians of the Later Roman Empire: Eunapius, Olympiodorus, Priscus and Malchus: Text, Translation, and Historiographical Notes, ed. R.C. Blockley, vol. II, Liverpool 1983.

Oribasii Collectionum medicarum eclogae medicamentorum [w:] Oribasii Collectionum medicarum reliquiae, vol. IV, libros XLIX-L, libros incertos, Eclogace medicamentorum, indicem continens, ed. I. Raeder, Lipsiae-Berolini 1933.

Orybazjusz, Oribasii Collectionum medicarum reliquiae, ed. I. Raeder, vol. I-IV, LipsiaeBerolini 1928-1933 [Coll.].

Orybazjusz, Oribasii Libri ad Eunapium [w:] Oribasii Synopsis ad Eustathium filium et Libri ad Eunapium, ed. I. Raeder, vol. VI, 3, Lipsiae 1964 [Lib.].

Orybazjusz, Oribasii Synopsis ad Eustathium filium [w:] Oribasii Synopsis ad Eustathium filium et Libri ad Eunapium, ed. I. Raeder, vol. VI, 3, Lipsiae 1964 [Syn.].

Palladiusz, Palladii Rutilii Tauri Aemiliani viri inlustris Opus agriculturae, De veterinaria medicina, De insitione, ed. R.H. Rodgers, Leipzig 1975.

Paweł, Paulus Aegineta, ed. I.L. Heiberg, vol. I-II, Lipsiae-Berolini 1921-1924.

Pliniusz, C. Plini Secundi naturalis historiae libri XXXVII, ed. C. Mayhoff, vol. I-V, Lipsiae 1892-1909.

Rose V., Die Diätetik des Anthimus an Theuderich König der Franken, in: Anecdota graeca et graecolatina. Mitteilungen aus Handschriften zur Geschichte der griechischen Wissenschaft, ed. V. Rose, vol. 2, Berolini 1870, 41-102.

Teofanes, Theophanis Chronographia, rec. C. de Boor, vol. I, Leipzig 1883.

Teofylakt, Theophylacti Simocattae Historiae, ed. C. de Boor, Leipzig 1887. 


\section{Opracowania}

Adams J., Bilingualism and the Latin Language, Cambridge 2003.

Asfora Nadler W., Collecting and Interpreting Apicius in Fifteenth-Century Italy Manuscript Tradition and Circulation of Culinary/Dietary Knowledge, „Food and History” 2016, vol. 14, no. 2/3, s. 183-203.

Baldwin B., The Career of Oribasius, „Acta Classica” 1975, vol. 18, s. 85-97.

Bonifay M., Pieri D., Merovingian Gaul and the Mediterranean: Ceramics and Trade [w:] The Oxford Handbook of the Merovingian World, eds. B. Effors, I. Moreira, Oxford 2020, s. 860-882.

Boudon-Millot V., Introduction générale [w:] Galien. Tome I: Introduction générale, Sur l'ordre de ses propres livres, Sur ses propres livres, Que l'excellent médecin est aussi philosophe, trad. V. Boudon-Millot, Paris 2007, s. VII-CCXXXVIII.

Bouras-Vallianatos P., Clinical Experience in Late Antiquity: Alexander of Tralles and the Therapy of Epilepsy, „Medical History” 2014, vol. 58, no. 3, s. 337-353.

Bouras-Vallianatos P., Galen in Byzantine Medical Literature [w:] Brill's Companion to the Reception of Galen, eds. P. Bouras-Vallianatos, B. Zipser, Leiden-Boston 2019, s. 86-110.

Bouras-Vallianatos P., Galen in Late Antique Medical Handbooks [w:] Brill's Companion to the Reception of Galen, eds. P. Bouras-Vallianatos, B. Zipser, Leiden-Boston 2019, s. 38-61.

Bouras-Vallianatos P., Galen's Reception in Byzantium: Symeon Seth and his Refutation of Galenic Theories on Human Physiology, „Greek Roman and Byzantine Studies” 2015, vol. 55, s. 431-469.

Buzzi S., La "forma breve" come paradigma compositivo nella produzione scientifica di epoca tardoantica: il caso di Oribasio [w:] Forma breve, eds. D. Borgogni, G.P. Caprettini, C. Vaglio Marengo, Torino 2016, s. 192-201.

Buzzi S., Polemica e controversia nel Corpus Oribasianum, „Medicina nei Secoli: Arte e Scienza" 2017, vol. 29, no. 3, s. 943-970.

Buzzi S., Calà I., Le ricette cosmetiche nelle enciclopedie mediche tardoantiche [w:] Collecting Recipes: Byzantine and Jewish Pharmacology in Dialogue, eds. L. Lehmhaus, M. Martelli, Berlin-Boston 2017, s. 123-146.

Caparrini M., Per un approfondimento dei germanismi dell'Epistula Anthimi de observatione ciborum: bridum/spiss, sodinga/prue, „Linguistica e Filologia” 2009, vol. 29, s. $179-196$.

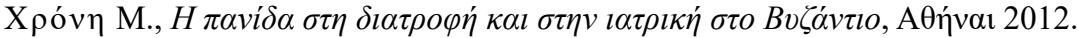

Cobb M., Black Pepper Consumption in the Roman Empire, ,Journal of the Economic and Social History of the Orient" 2018, vol. 61, no. 4, s. 519-559.

Cobb M.A., The Reception and Consumption of Eastern Goods in Roman Society, „Greece \& Rome" 2013, vol. 60, no. 1, s. 136-152.

Dalby A., Dangerous Tastes: The Story of Spices, London 2000.

Dalby A., Empire of Pleasures: Luxury and Indulgence in the Roman Empire, London 2000.

Dalby A., Flavours of Byzantium, Blackawton-Totnes 2003.

Dalby A., Food in the Ancient World from A to Z, London-New York 2003.

Dalby A., Siren Feasts: A History of Food and Gastronomy in Greece, London-New York 1996.

Dalby A., Tastes of Byzantium: The Cuisine of a Legendary Empire, London-New York 2010.

De Lucia R., Oreibasios v. Pergamon [w:] Antike Medizin. Ein Lexikon, ed. K.-H. Leven, München 2005, kol. 660-661. 
Deroux C., Anthime et les tourterelles: un cas d'intoxication alimentaire au très haut moyen âge [w:] Maladie et maladies dans les textes latins antiques et médiévaux. Actes du Ve Colloque international "Textes médicaux latins» [Bruxelles, 4-6 septembre 1995], ed. C. Deroux, Bruxelles 1998, s. 366-381.

Deroux C., Anthime, un médecin gourmet du début des temps mérovingiens, „Revue Belge de Philologie et d'Histoire" 2002, vol. 80, no. 4, s. 1107-1124.

Deroux C., The Allusion by Anthimus the Physician to the Cauterisation of Horses (De obs. cib., praef., p. 3, l. 6-8 Liechtenhan) [w:] Studies in Latin Literature and Roman History, ed. C. Deroux, Bruxelles 2005, s. 484-493.

Deroux C., The Franks and Bacon According to Doctor Anthimus (De obs. cib. 14) [w:] Studies in Latin Literature and Roman History, ed. C. Deroux, Bruxelles 2008, s. 518 528.

Deroux C., Le médecin Anthimus et le vocabulaire de la diagnose [De obs. cib. 25: agnoscens], „Latomus” 2015, vol. 74, no. 2, s. 491-493.

Deroux C., Des traces inconnues de la "Diététique" d'Anthime dans un manuscrit du Vatican “(Reg. Lat. 1004)”, „Latomus” 1974, vol. 33, no. 3, s. 680-687.

Diller H., Paulos (23) [w:] RE, vol. 18.4, Stuttgart 1949, kol. 2386-2397.

Effros B., Creating Community with Food and Drink in Merovingian Gaul, New YorkHoundmills, Basingstoke 2002.

Eijk van der Ph., Principles and Practices of Compilation and Abbreviation in the Medical 'Encyclopaedias' of Late Antiquity [w:] Condensing Texts - Condensed Texts, eds. M. Horster, Ch. Reitz, Stuttgart 2010, s. 519-554.

Faas P., Around the Roman Table. Food and Feasting in Ancient Rome, transl. S. Whiteside, Chicago 2005.

Fischer K.-D., Ein brennendes Problem: Anthimus, praef., p. 3, 6, Liechtenhan, „Latomus” 1989, vol. 48, no. 4, s. 880-881.

Garzya A., Aetios v. Amida [w:] Antike Medizin. Ein Lexikon, ed. K.-H. Leven, München 2005, kol. 19-20.

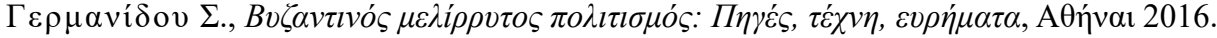

Gowling E., Aëtius'Extraction of Galenic Essence: A Comparison Between Book 1 of Aetius'Libri Medicinales and Galen's On Simple Medicines [w:] Collecting Recipes. Byzantine and Jewish Pharmacology in Dialogue, eds. L. Lehmhaus, M. Martelli, Boston-Berlin 2017, s. 83-101.

Grant M., Introduction [w:] Anthimus, On the Observance of Foods. De observatione ciborum, ed., transl. M. Grant, Blackawton-Totnes 2007, s. 9-44.

Grant M., Oribasios and Medical Dietetics or the Three Ps, [w:] Food in Antiquity, eds. J. Wilkins, D. Harvey, M. Dobson, Exeter 1995, s. 368-379.

Grant M., A Problematical Word in Anthimus' "De Observatione Ciborum Epistula" 43, „Rheinisches Museum für Philologie, Neue Folge” 1993, vol. 136, no. 3/4, s. 377-379.

Grocock Ch., Grainger S., Appendix: A Glossary to Apicius [w:] Apicius. A Critical Edition with an Introduction and an English Translation of the Latin Recipe Text Apicius, eds. Ch. Grocock, S. Grainger, Blackawton-Totnes 2006, s. 329-362.

Grocock Ch., Grainger S., Introduction [w:] Apicius: A Critical Edition with an Introduction and an English Translation of the Latin Recipe Text Apicius, Blackawton-Totnes 2006, s. 13-123.

Hen Y., Food and Drink in Merovingian Gaul [w:] Tätigkeitsfelder und Erfahrungshorizonte des ländlichen Menschen in der frühmittelalterlichen Grundherrschaft (bis ca. 1000): Festschrift für Dieter Hägermann zum 65. Geburtstag, ed. B. Kasten, München 2006, s. 99-110.

Heyd W., Geschichte des Levantehandels im Mittelalter, vol. 1-2, Stuttgart 1879. 
Hohlweg A., Medizinischer 'Enzyklopädismus'und das ПONHMA IATPIKON des Michael Psellos, „Byzantinische Zeitschrift” 1988, vol. 81, s. 39-49.

Hunger H., Die hochsprachliche profane Literatur der Byzantiner, vol. I-II, München 1978. Jagusiak K., Kokoszko M., Pisma Orybazjusza jako źródło informacji o pożywieniu ludzi w późnym Cesarstwie Rzymskim, „Vox Patrum”2013, vol. 59, s. 339-357.

Jagusiak K., Kokoszko M., Życie i kariera Orybazjusza $w$ świetle relacji źródłowych, „Przegląd Nauk Historycznych” 2011, t. 10, nr 1, s. 5-21.

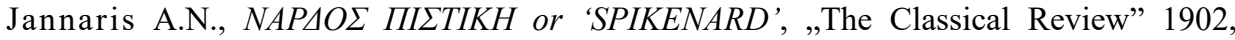
vol. 16, no. 9, s. 459-460.

Keyser P.T., Poluarkhos (30 BCE-35 CE) [w:] The Encyclopedia of Ancient Natural Scientists. The Greek Tradition and its Many Heirs, eds. P.T. Keyser, G. Irby-Massie, London-New York 2008, s. 680.

Koder J., Die Byzantiner Kultur und Alltag im Mittelalter, Wien-Köln-Weimar 2016.

Koder J., Cuisine and Dining in Byzantium [w:] Byzantine Culture, Papers from the Conference 'Byzantine Days of Istanbul' Held on the Occasion of Istanbul being European Cultural Capital 2010, Istanbul, May 21-23 2010, ed. D. Sakel, Ankara 2014, s. 423-438.

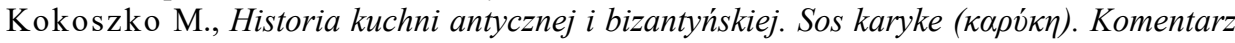
do Chronografii Michała Psellosa, „Przegląd Nauk Historycznych” 2006, t. 5, nr 2(10), s. $167-178$.

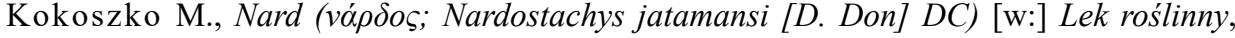
Tom VI: Rośliny $w$ lecznictwie, $w$ środowisku naturalnym $i$ w krajobrazie kulturowym, red. B. Płonka-Syroka, A. Syroka, Wrocław 2017, s. 31-51.

Kokoszko M., Some Technical Terms from Greek Cuisine in Classical and Byzantine Literature, „Eos” 2008, vol. 95, s. 269-283.

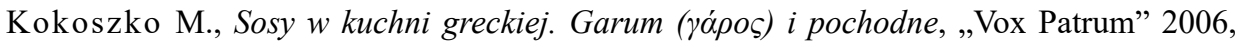
vol. 49, s. 289-298.

Kokoszko M., Jagusiak K., Rzeźnicka Z., Dietetyka i sztuka kulinarna antyku i wczesnego Bizancjum (II-VII w.), część I, Zboża i produkty zbożowe w źródtach medycznych antyku i wczesnego Bizancjum (II-VII w.), Łódź 2014.

Kokoszko M., Jagusiak K., Rzeźnicka Z., Dybała J., Pedanius Dioscorides' Remarks on Milk Properties, Quality and Processing Technology, „Journal of Archaeological Science: Reports" 2018, vol. 19, s. 982-986.

Kokoszko M., Rzeźnicka Z., Malábathron ( $\mu \alpha \lambda \dot{\alpha} \beta \alpha \theta \rho o v)$. Kilka uwag o roli Cinnamomum tamala $w$ kuchni i medycynie antyku i Bizancjum $w$ okresie pomiędzy I a VII wiekiem, „Przegląd Nauk Historycznych” 2016, t. 15, nr 1, s. 5-42.

Kokoszko M., Rzeźnicka Z., Malabathron ( $\mu \alpha \lambda \dot{\alpha} \beta \alpha \theta \rho o v)$ in Ancient and Early Byzantine Medicine and Cuisine, „Medicina nei Secoli: Arte e Scienza” 2018, vol. 30, no. 2, s. 579-616.

Kokoszko M., Rzeźnicka Z., Jagusiak K., Health and Culinary Art in Antiquity and Early Byzantium in the Light of De re coquinaria, „Studia Ceranea: Journal of the Waldemar Ceran Research Centre for the History and Culture of the Mediterranean Area and South-East Europe" 2012, vol. 2, s. 145-164.

Kripouri P., Filippou D., On the Work of Alexander of Tralles, „Acta Medico-Historica Adriatica" 2019, vol. 17, no. 2, s. 295-304.

Lapoujade Lejavitzer A., Dieta saludable, alimentos puros y purificación en el mundo grecolatino, „Nova Tellus. Revista semestral del Centro de Estudios Clásicos” 2016, vol. 34, no. 1, s. 109-121.

Lapoujade Lejavitzer A., Terminología culinaria en De re coquinaria: lengua técnica y coincidencias con el latín vulgar, „Nova Tellus. Revista semestral del Centro de Estudios Clásicos” 2020, vol. 38, no. 2, s. 83-97. 
Laurioux B., Cuisiner à l'Antique: Apicius au Moyen Age, „Médiévales” 1994, vol. 26, s. $17-38$.

Laurioux B., Spices in the Medieval Diet: A New Approach, „Food and Foodways: Explorations in the History and Culture of Human Nourishment" 1985, vol. 1, s. 43-75.

Lev E., Amar Z., Practical Materia Medica of the Medieval Eastern Mediterranean According to the Cairo Genizah, Leiden-Boston 2008.

Liechtenhan E., Brief des Anthimus des erlauchten Comes und Gesandten and den ruhmreichen Theoderich, der König der Franken, über Speisediät [w:] Anthimi De observatione ciborum ad Theodoricum regem Francorum epistula, iteratis curis edidit et in linguam Germanicam transtulit E. Liechtenhan, Berlin 1963, 34- 47.

Mattern S.P., The Prince of Medicine: Galen in the Roman Empire, Oxford 2013.

Messing G.M., Remarks on Anthimus De observatione ciborum, „Classical Philology” 1942, vol. 37, no. 2, s. 150-158.

Mikołajczyk I., Wyszomirski S., Wstęp [w:] Apicjusz, O sztuce kulinarnej ksiag dziesięć, thum. I. Mikołajczyk, S. Wyszomirski, Torun 2012, s. 3-13.

Murphy T., Pliny the Elder's Natural History: The Empire in the Encyclopedia, OxfordNew York 2004.

Nutton V., Ancient Medicine, London-New York 2005.

Nutton V., From Galen to Alexander. Aspects of Medicine and Medical Practice in Late Antiquity, „Dumbarton Oaks Papers” 1984, vol. 38, s. 1-14.

Passabì A., Dagli scritti di Oribasio: L'uso di É $\gamma \omega ́$ e correlati negli excerpta di Rufo e nella testimonianza personale dello stesso Oribasio, „Rudiae: Ricerche sul mondo classico” 2007, vol. 19, s. 71-138.

Pion C., Gratuze B., Périn P., Calligaro T., Bead and Garnet Trade between the Merovingian, the Mediterranean, and Indian Worlds [w:] The Oxford Handbook of the Merovingian World, eds. B. Effros, I. Moreira, Oxford-New York 2020, s. 819-859.

Plouvier L., L'alimentation carnée au Haut Moyen Âge d'après le De observatione ciborum d'Anthime et les Excerpta de Vinidarius, „Revue belge de philologie et d'histoire” 2002, vol. 80, no. 4, s. 1357-1369.

Pormann P., The Oriental Tradition of Paul of Aegina's Pragmateia, Leiden 2004.

Pormann P., Paulos v. Aigina [w:] Antike Medizin. Ein Lexikon, ed. K.-H. Leven, München 2005, kol. 681-682.

Prérez Martín I., Manolova D., Science Teaching and Learning Methods in Byzantium [w:] A Companion to Byzantine Science, ed. S. Lazaris, Leiden-Boston 2020, s. 53-104.

Prioreschi P., A History of Medicine, vol. V. Medieval Medicine, Omaha, NE 2003.

Riddle J.M., Dioscorides on Pharmacy and Medicine. Foreword by J. S arb orough, Austin 1985.

Rodgers R.H., L. Iunius Moderatus Columella of Gades (ca 40-ca 70 CE [w:] The Encyclopedia of Ancient Natural Scientists. The Greek Tradition and its Many Heirs, eds. P.T. Keyser, G. Irby-Massie, London-New York 2008, s. 456-457.

Rodgers R.H., Palladius Rutilius Taurus Aemilianus (ca 375-ca 450 CE) [w:] The Encyclopedia of Ancient Natural Scientists. The Greek Tradition and its Many Heirs, eds. P.T. Keyser, G. Irby-Massie, London-New York 2008, s. 35-36.

Rzeźnicka Z., Kokoszko M., Dietetyka i sztuka kulinarna antyku i wczesnego Bizancjum

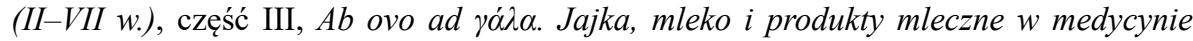
$i$ w sztuce kulinarnej (I-VII w.), Łódź 2016.

Rzeźnicka Z., Kokoszko M., Milk and Dairy Products in the Medicine and Culinary Art of Antiquity and Early Byzantium (1st-7th Centuries AD), Łódź-Kraków 2020.

Scarborough J., Anthimus (of Constantinople?) (ca 475-525 CE) [w:] The Encyclopedia of Ancient Natural Scientists. The Greek Tradition and its Many Heirs, eds. P.T. Keyser, G. Irby-Massie, London-New York 2008, s. 91-92. 
Scarborough J., Diphilus of Siphnos and Hellenistic Medical Dietetics, „Journal of the History of Medicine and Allied Sciences" 1970, vol. 25, no. 2, s. 194-201.

Scarborough J., Early Byzantine Pharmacology, „Dumbarton Oaks Papers” 1984, vol. 38, s. 224-226.

Schoff W.H., Nard, „Journal of the American Oriental Society” 1923, vol. 43, s. 216-228.

Solomon J., The Apician Sauce - Ius Apicianum [w:] Food in the Ancient World, eds. J. Wilkins, D. Harvey, M. Dobson, Exeter 1995, s. 115-131.

Stewart K.A., Galen's Theory of Black Bile: Hippocratic Tradition, Manipulation, Innovation, Leiden-Boston 2019.

Talbot A.-M., Mealtime in Monasteries: The Culture of the Byzantine Refectory [w:] Eat, Drink, and Be Merry (Luke 12:19) - Food and Wine in Byzantium Papers of the 37th Annual Spring Symposium of Byzantine Studies, in Honour of Professor A.A.M. Bryer, eds. L. Brubaker, K. Linardou, Aldershot-Burlington, VT 2007, s. 109-125.

Thibodeau P., Diophanēs of Nikaia (85-60 BCE) [w:] The Encyclopedia of Ancient Natural Scientists. The Greek Tradition and its Many Heirs, eds. P.T. Keyser, G. Irby-Massie, London-New York 2008, s. 267.

Totelin L., When Foods Become Remedies in Ancient Greece: The Curious Case of Garlic and Other Substances, ,Journal of Ethnopharmacology” 2015, vol. 167, s. 30-37.

Totelin L.M.V., Therapeutics [w:] The Cambridge Companion to Hippocrates, ed. P.E. Pormann, Cambridge-New York 2018, s. 200-216.

Touwaide A., Botany [w:] A Companion to Byzantine Science, ed. S. Lazaris, Leiden-Boston 2020, s. 302-353.

Touwaide A., Medicine and Pharmacy [w:] A Companion to Byzantine Science, ed. S. Lazaris, Leiden-Boston 2020, s. 354-403.

Weberling F., On the Systematics of Nardostachys, ,Taxon” 1975, vol. 24, no. 4, s. 443-452.

Wilkins J., Good Food and Bad: Nutritional and Pleasurable Eating in Ancient Greece, „Journal of Ethnopharmacology” 2015, vol. 167, s. 7-10. 